\title{
Roman whetstone production in northern Gaul (Belgium and northern France)
}

\author{
Aurélie Thiébaux ${ }^{1}$, Marc Feller ${ }^{2}$, Bruno Duchêne ${ }^{3}$, Eric Goemaere ${ }^{4}$ \\ 1. University of Liège. Quai Roosevelt 1B, 4000 Liège, Belgium. Email: a.thiebaux@ulg.ac.be \\ 2. Institut national de recherches archéologiques préventives (Inrap), Halma-Ipel UMR 8164 (Lille3-CNRS- \\ MCC). Rue de Méric 12, 57063 Metz, France. Email: marc.feller@inrap.fr \\ 3. Institut national de recherches archéologiques préventives (Inrap). Rue Robert Fulton 28, 51689 Reims, \\ France. Email: bruno.duchene@inrap.fr \\ 4. Geological Survey of Belgium, Royal Belgian Institute of Natural Sciences. Rue Jenner 13, 1000 Brussels, \\ Belgium. Email: eric.goemaere@naturalsciences.be
}

\begin{abstract}
:
This paper focuses on the latest research on the production of Roman whetstones in northern Gaul. To date, little has been written about this specialised industry. However, three workshops producing whetstones were discovered recently in the north of Gaul in Buizingen (Province of Flemish Brabant, Belgium), Nereth (Province of Liège, Belgium) and Le Châtelet-sur-Sormonne (Department of Ardennes, France). Production debris and rough-outs recovered at these sites allowed us to reconstruct the operational sequence of manufacture, from the choice of raw material to the finished product. Technological studies enabled us to determine the production stages and highlight the similarities and differences between the three study areas. Analyses of the materials reveal the use of fine-grained sedimentary and low-grade metamorphic rocks outcropping near the workshops. All these rocks are linked to the Caledonian inliers of Brabant-London, Stavelot-Venn, and Rocroi. The large amount of waste found at Le Châtelet-sur-Sormonne, far more than that recovered at Buizingen and Nereth, is indicative of the economic importance of this whetstone workshop. This importance is reflected in the fact that whetstones from Le Châtelet-sur-Sormonne are distributed over a large area throughout Belgium, France (Nord-Pas-de-Calais, Picardie and Champagne-Ardenne regions), Germany, and the Netherlands. This paper presents the waste and rough-outs from the three production sites. It also defines rock types and their origins and offers insights into whetstone manufacturing processes and techniques.
\end{abstract}

Keywords: whetstones; provenance; Roman period; northern Gaul; Belgium; northern France; ground stone tools

\section{Introduction}

A whetstone is a tool made with a fine-grained stone, typically sandstone, and usually used with water to sharpen a variety of cutting tools from different contexts (domestic, commercial, agricultural, medical, industrial, and military) (Allen 2014: 1). A hone or razor

Published by the School of History, Classics and Archaeology, University of Edinburgh ISSN: 2055-0472. URL: http://journals.ed.ac.uk/lithicstudies/

This work is licensed under a Creative Commons Attribution 2.5 UK: Scotland License. 
hone, in turn, is principally used to sharpen the blades of razors. These modest but clearly vital tools have received little attention from archaeologists until about 10 years ago.

As noted by Allen (2014: 2), the properties of good whetstones are that they contain well-sorted hard and soft components of appropriate size and shape. The grains should be hard enough to cut metal and thus sharpen it. Examples of such grains are spessartite crystals (a manganese-garnet with a hardness of 7-7.5 on the Mohs scale) of the world-renowned razor hone fashioned from the "Belgian coticule" rock (Goemaere 2007: 57-65) and quartz found in certain sedimentary or metamorphic rocks. Whilst quartz (with a hardness of 7 on Mohs scale) is the main mineral in sedimentary rocks, any mineral with hardness greater than six can sharpen iron blades. These include feldspars and heavy minerals such as zircon, tourmaline, and rutile.

Considering the frequent use of metal utensils in everyday life and in various economic activities, it is not surprising that whetstones are common finds on sites (towns and rural settlements, as well as craft sites) throughout the Roman Empire. However, for a long time, archaeologists ignored these artefacts. Today they are integrated into the economic study of archaeological sites and recent studies reveal fruitful collaborations between geologists and archaeologists (Chardron-Picault \& Pernot 1999: 183-185; Brulet et al. 2008: 191; Henrich et al. 2008; Van der Velde et al. 2009: 233-235; Thiébaux et al. 2012; Thiébaux \& Goemaere 2013; in press; Dreesen et al. 2014).

Whetstones in Roman times fall into two main groups: "natural" stones and manufactured stones (Figure 1). Natural whetstones are defined as pebbles or rounded stones collected from riverbeds or terrace deposits, or detached from naturally fractured outcrops in the form of small slabs or blocks. The second group corresponds to whetstones produced in workshops that are likely to be widely distributed. In general, workshops yielded two main shapes of whetstones (with different cross-sections): parallelepiped with rectangular or square cross-sections and elliptic or circular cylinders named respectively "bar-shaped and rodshaped” by Allen (2014: 7). Although a general typology of whetstones is currently being developed by the present authors and other colleagues, local typologies have been advanced by Kars (1983), Deberge et al. (2007: 180), Henrich et al. (2008), Allen (2014: 6-7). Whitehead (2013), for example, provides a limited description of whetstones from Worcestershire, England spanning 4000 years.

This paper centres on whetstone production in northern Gaul, with a particular focus on how the material was extracted and processed. This work was carried out in the framework of a $\mathrm{PhD}$ thesis at the University of Liège (Belgium) on raw material, production, use, trade, and typology of Roman whetstones between the Seine and the Rhine Rivers in northern Gaul.

Whilst finished whetstones are commonly found at Roman sites, the discovery of workshops and their production waste is much rarer for this period than for later periods. Two productions are documented in Roman Britain. The first is reported by Atkinson (1942: 128130) at Wroxeter in the Welsh Borders region. About 100 unused parallelepiped whetstones, possibly belonging to a shop, were found in a Forum gutter dating to the late $2^{\text {nd }}$ century A.D. Characterised by a series of manufacturing marks, they were hewn from sandstones from the Mesozoic Early Lower Cretaceous Weald Clay Formation outcrops, in south-east England. A major whetstone industry exploiting the Weald Clay Formation existed during Roman times and many whetstones of this material have been found in England (Allen 2014: 9). The second example of whetstone production is at the Roman fortress in Usk (in south-east Wales) where rough-outs and debris were recovered in pre-Flavian pits. This workshop produced parallelepiped whetstones of sandstone or siltstone from the Brownstones Formation of Lower Old Red Sandstone outcropping near Usk (Manning 1995: 257-258). Based on current evidence, distribution of Usk whetstones seems to be limited to the fortress (Allen 2014: 9). 


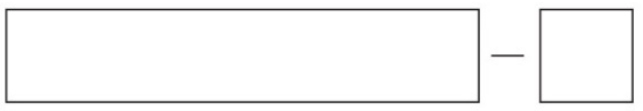

Parallelepiped with square cross-section

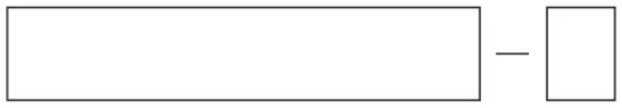

Parallelepiped with rectangular cross-section

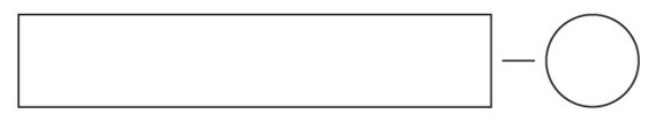

Circular cylinder

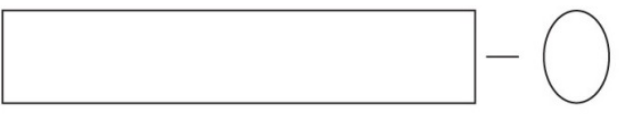

Elliptic cylinder
1

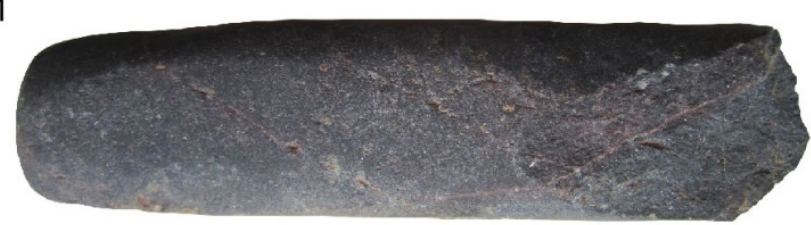

2

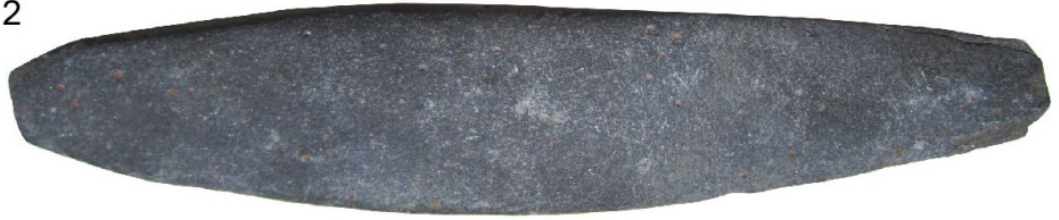

3

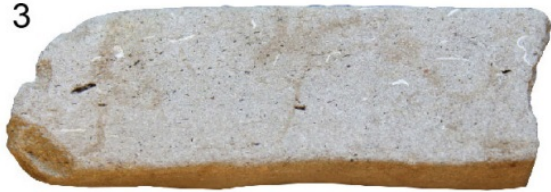

4

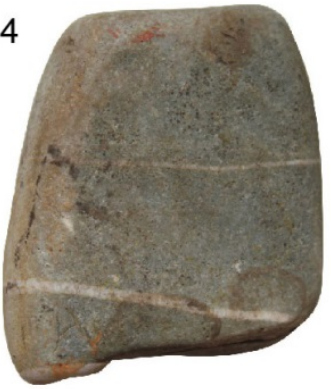

Figure 1. Simplified whetstone typology and examples of Gallo-Roman whetstones from Les Rues-des-Vignes, Department of Nord, France. 1 and 2. Cylindrical whetstones fashioned from (1) blackish siltstone and (2) dark grey fine-grained sandstone (Petite-Commune Formation, Revin group, Lower Palaeozoic); 3. Parallelepiped whetstone fashioned from pale grey calcite-cemented fossiliferous sandstone (Cretaceous, Upper Mesozoic); 4. Fluvial grey quartzite pebble (Cambrian or Lower Devonian, Palaeozoic) with white quartz veins ("natural" whetstone).

Elsewhere, recent excavations have also revealed three workshops in Northern Gaul, the object of this study. Two are in Belgium (Nereth and Buizingen), while the third is by the town of Le Châtelet-sur-Sormonne in northern France (Figure 2). The aims of this paper are the following: to present these three workshops and their lithic artefacts, to reconstruct the manufacturing processes of parallelepiped and cylindrical whetstones, to describe the lithological nature of the raw material, to study the geological and the geographical provenance of the raw material, and finally, to estimate the area of distribution of the finished whetstones. In addition to the rock exploited by the three workshops, other rocks were used to make Gallo-Roman whetstones. No quarry or workshop of these rocks, to date, has been discovered.

\section{Methods}

The three whetstones workshops under study are characterised by production debris, that is, many rough-outs and stone flakes discarded during the different stages of manufacture.

\subsection{The workshop of Buizingen (Hal, Province of Flemish Brabant, Belgium)}

Members of the Cercle d'Histoire, d'Archéologie et de Folklore d'Uccle (BrusselsCapital Region), aided by the Service national des Fouilles, excavated a Roman cellar at 
Buizingen in September, 1967. This work was carried out in the framework of the construction of the E19 motorway linking Mons to Brussels (Figure 2).

The square cellar, approximately $2 \times 2 \mathrm{~m}$ with a stairway $0.78 \mathrm{~m}$ wide, was partially destroyed by modern road works (two of its walls were cut). The evidence clearly indicates that the feature had originally been abandoned after a fire. The brief study of the site's ceramic in 1967 (unfortunately not preserved) placed the cellar's abandonment roughly between the second half of the $2^{\text {nd }}$ to the $3^{\text {rd }}$ century AD. The function of other buildings near this structure remains unclear (Pierrard 2010a; 2010b; 2011a; 2011b).

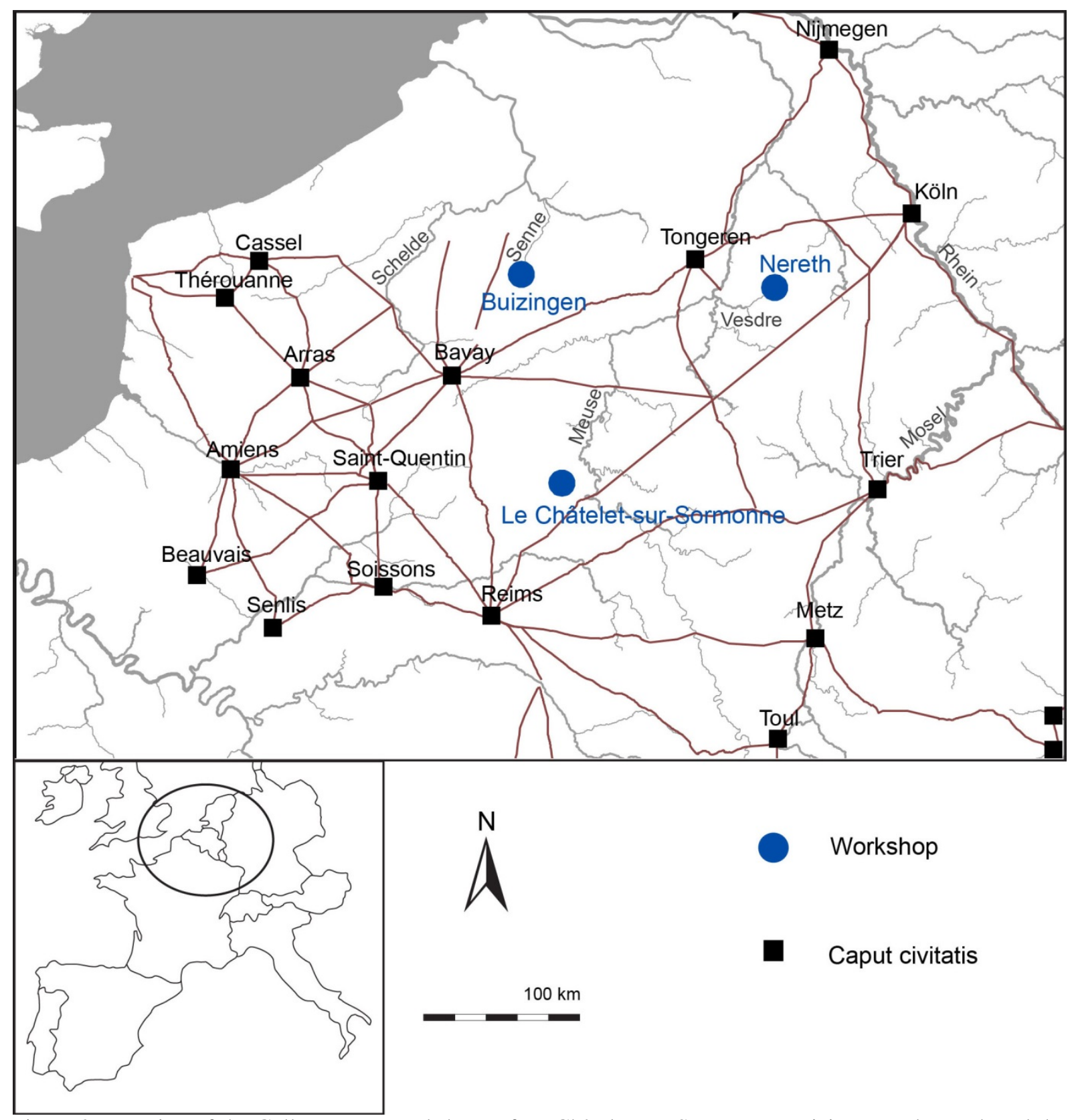

Figure 2: Location of the Gallo-Roman workshops of Le Châtelet-sur-Sormonne, Buizingen and Nereth and the main roads and civitates capitals in northern Gaul.

Artefacts at the site included ceramic, tiles and millstone fragments. Yet the most interesting finds were the traces of a whetstone workshop including 102 rough-outs and other production waste currently stored in the Museum of Centre Public d'Aide Social in Brussels and in the Zuidwestbrabants Museum of Hal. The Buizingen workshop produced three main 
types: 1) parallelepiped with rectangular cross-section, 2) elliptic, and 3) circular cylinder (Thiébaux et al. 2012).

The geological portrait of the Buizingen whetstones is based on macroscopic observation, microscopic petrography on thin sections, comparisons with geological materials collected in the field from outcrops and riverbeds, as well as reference collections of the Belgian Geological Survey. The same methods were applied to the finds of Nereth and Le Châtelet-sur-Sormonne.

The Buizingen rocks included light green, very fine silty to coarser-grained quartzitic sandstones, feldspathic sandstones, arkoses and greywackes. The grains of the coarse rocks are poorly sorted and contain sub-angular to sub-rounded lithic fragments. The stratification plane is clearly visible on some samples. Minute grains and crystals of magnetite are present in the majority of the samples, as seen on polished slabs and thin sections. High magnetic susceptibility or MS value, measured using the SM30 from ZH instruments and Kappabridge magnetic susceptibility meters from the Geological Survey of Belgium, are linked to the concentration of magnetic grains. The measurements obtained range from between 0.98 and $58.5 \mathrm{E}-6 \mathrm{~kg} / \mathrm{m}^{3}$, corresponding to very high values. These sets of high MS values characterise the Rogissart Member, the lowermost member of the Tubize Formation (Early Cambrian, Lower Palaeozoic) outcropping in the Brabant-London inlier. Other Lower Palaeozoic rocks from Belgian Caledonian inliers have lower values $\left(<1 \mathrm{E}-6 \mathrm{~kg} / \mathrm{m}^{3}\right)$ due to the absence of grains of magnetite. Descriptions of the litho-stratigraphical units in the Cambro-Silurian BrabantLondon inlier are advanced by Verniers et al. (2001) and Herbosch et al. (2013). For more cartographic details of the Rogissart Member and Tubize Formation, see Thiébaux et al. (2012).

The Rogissart Member is found to the south in the Senne Valley, $4.5 \mathrm{~km}$ from Buizingen (Figure 3). Outcrops are rare and, historically, were exploited in modest modern quarries with very small working faces that are now backfilled with waste. The Saint-Martin basilica of Hal and a few old houses around Buizingen were built with this rock, often today referred as "Arkose de Tubize".

\subsection{The small whetstone workshop at Nereth (Baelen, Province of Liège, Belgium)}

In 2003, the Direction de l'archéologie (Public Services Department of the Walloon government) carried out excavations at Nereth in eastern Belgium prior to construction of a high speed train (Figure 2). The excavations, near an early Roman settlement, revealed two wooden post-built houses dating to the Late Empire. The first covered an area of more than 80 $\mathrm{m}^{2}(12.5 \times 6.5 \mathrm{~m})$. The second was only partially explored (only the north and west walls were excavated). These features were surrounded by pits. The house type and the objects (ceramics and metal objects) indicate a Germanic occupation from the second quarter of the $4^{\text {th }}$ century AD until the beginning of the $5^{\text {th }}$ century AD (Hanut et al. 2012: 243-254; 2013). New excavations are currently being carried by the Direction de l'archéologie in this area.

Evidence of whetstone working was found among the site's different features (houses and pits), notably two rough-outs, one off-cut, four finished products and fourteen flakes, with or without manufacturing marks. Based on the finished products, this workshop produced parallelepiped whetstones (Hanut et al. 2013). Pebbles used as whetstones were also found in close association with manufactured examples. River pebbles made from quartzite and quartz veins probably come from the intersection of the Vesdre riverbed and the Caledonian Massif.

Both the rough-outs and finished whetstones are of a dark blue to dark grey, micaceous siltstone with minute crystals of pyrite and frequent dark blue cm-sized mud chips. The slatelike cleavage is well marked, while the stratification plane is not visible macroscopically. Their geological provenance is the Cambrian layers of the Revin Group, outcropping in the 
Caledonian Stavelot-Venn Massif. The Revin Group comprises dark to light grey coloured slates and quartzites, subdivided into the Wanne, La Venne and La Gleize formations (Verniers et al. 2001). However, a (bio) stratigraphic (and geographic) connection of the Nereth whetstones with one of these formations has not yet been established. This connection requires a complete HF-dissolution of the raw material in order to extract the content in the form of acritarchs thus providing the only useful tool to date the artefacts more precisely. Outcrops occur 10-15 km south of Nereth, mainly in the un-metamorphosed northern sector of the Stavelot-Venn Massif. Roman quarries are unknown in that area (Figure 3).

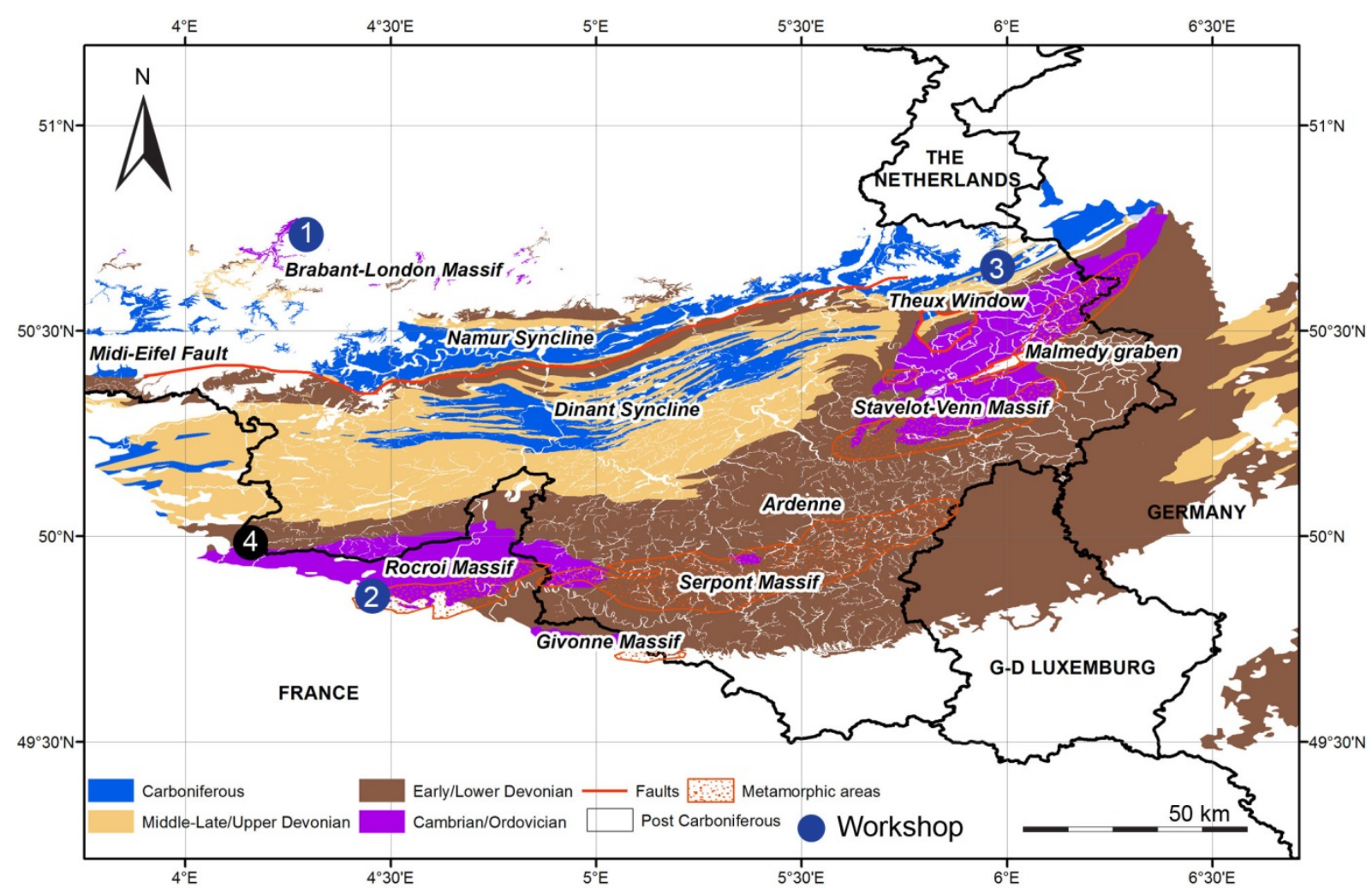

Figure 3: Geological map with the three workshops: (1) Buizingen, (2) Le Châtelet-sur-Sormonne, (3) Nereth and the millstone quarries of (4) Macquenoise and (in purple) the Lower Palaeozoic inliers. Map modified after Goemaere et al. (2015). The borders of the metamorphic areas are adapted from Fielitz \& Mansy (1999).

\subsection{The workshop of Le Châtelet-sur-Sormonne (Department of the Ardennes, France)}

In 2013, the Institut National de Recherches Archéologiques Préventives (Inrap, France) carried out excavations at Le Châtelet-sur-Sormonne near Charleville-Mézières prior to the construction of the A304 motorway (Figure 2). Archaeologists identified Roman burials and a settlement, comprising four main structures (a bath house and three cellars) abandoned between 250 and $270 \mathrm{AD}$. A large hoard containing thousands of whetstone rough-outs was found $50 \mathrm{~m}$ to the north of the settlement. All the whetstone rough-outs were partially broken, suggesting that they are production waste. Ceramics found in the hoard date it to the end of the $3^{\text {rd }}$ century AD. No buildings or other structures were uncovered in the immediate area. The study of this assemblage is still in progress and only unpublished and internal reports are available (Duchêne 2014).

Due to the large number of artefacts, not all of the rough-outs have been studied. A selection of 2,865 items was made by dividing the hoard into squares of equal size and collecting from one out of two squares. If the sampling is representative, then this hoard contains approximately 6,000 rough-outs. 
The finds indicate that this workshop also produced cylindrical whetstones with elliptical or circular cross-sections, some with a herringbone pattern carved over the entire surface (Figure 4). Whetstones with this type of pattern are the object of an on-going collaboration between the University of Gent (S. Reniere, Belgium), LVR-Archäologischer Park and LVRRömer Museum in Xanten (B. Liesen and J. Jäger, Germany).
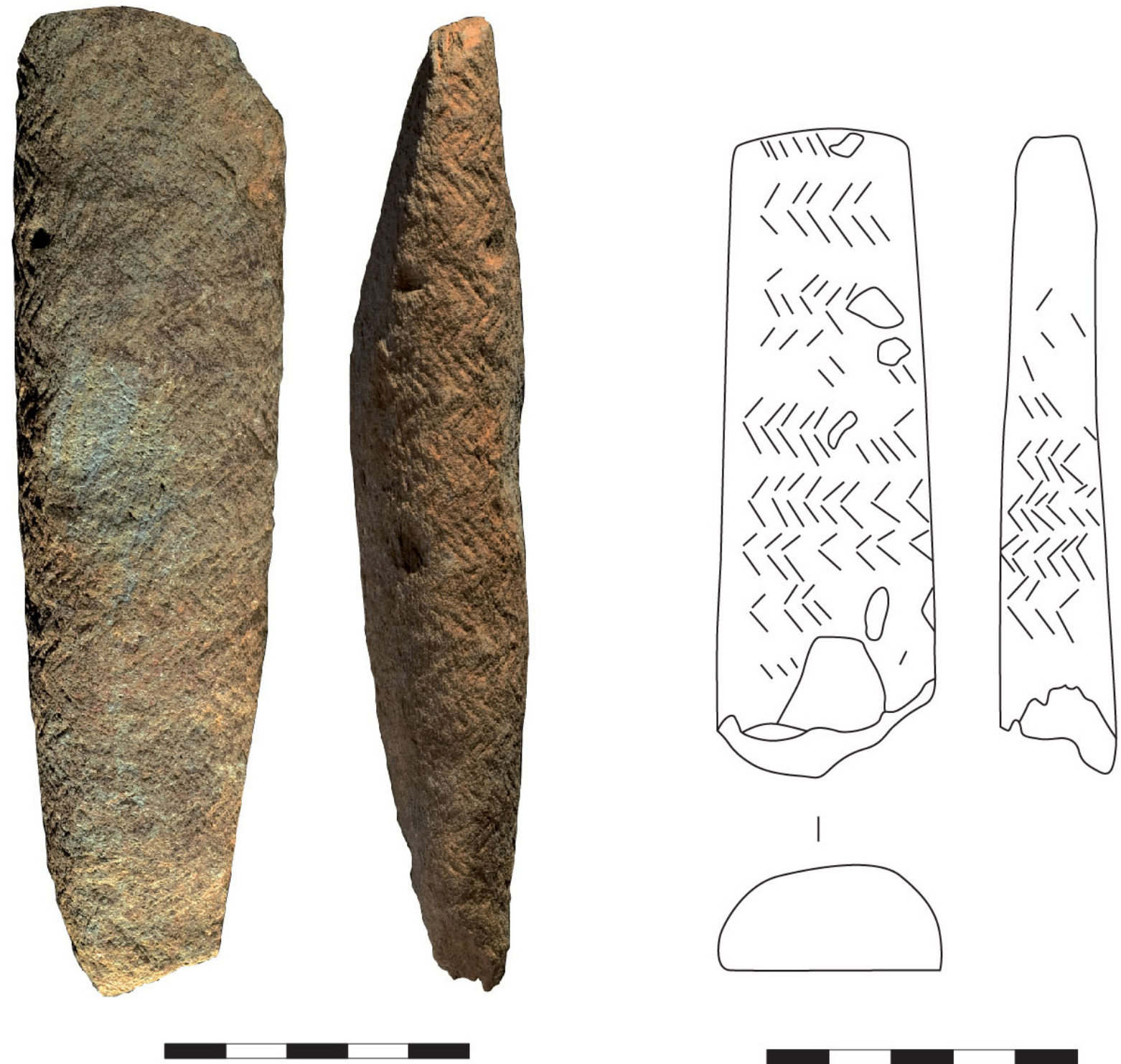

\section{$5 \mathrm{~cm}$}
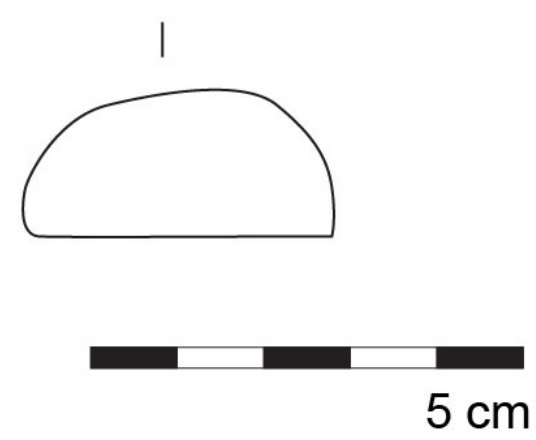

Figure 4: Cylindrical whetstones engraved with a herringbone pattern, Le Châtelet-sur-Sormonne, Photograph provided by S. Loiseau, Inrap; drawing by A. Thiébaux

The Le Châtelet-sur-Sormonne whetstones were made with two different rocks. The first lithotype, represented by $96.3 \%$ of the rough-outs, is a blue to dark blue micaceous siltstone or fine-grained well-sorted argillaceous sandstone with a slaty cleavage. The finer material of this type contains crystals of pyrite, while the coarser sandstone contains centimetre-sized dark mud chips. The intensity of colour is inversely proportional to the average grain size. Its black colour is due to the presence of finely disseminated organic matter. The thermal maturity of this material, studied at the Belgian Geological Survey by $\mu$ Raman Spectrometry, indicates a temperature higher than $300^{\circ} \mathrm{C}$, corresponding to a lower grade metamorphism 
affecting the southern flank of the Rocroi inlier. The second lithotype, represented by $3.7 \%$ of the rough-outs, is green micaceous sandstone. Its colour is due to flakes rich in Fe-chlorites identified by petrographic and XRD analyses.

The provenance of these two materials is in the Cambrian rocks of the Rocroi Massif. The blue sandstone and siltstone belongs to the Petite-Commune Formation (Revin Group, Middle and Upper Cambrian, Lower Palaeozoic), whereas the green sandstone is attributed to the La Longue-Haie Formation (Deville Group, Lower Cambrian, Lower Palaeozoic). This formation in the metamorphic area of the southern region of the Rocroi Massif is composed of an alternation of light green slate with magnetite crystals and light green fine-grained quartzite. Colours differ in the northern non-metamorphic area of the Rocroi Massif where the slates are green, purple or red. Further details regarding the lithological content of the Caledonian geological units of the Rocroi are presented by Verniers et al. (2001) and the cartographic details of the Rocroi inlier by Waterlot et al. (1960). A notable whetstone from Le Châtelet-sur-Sormonne is made from light green slate with pluri-millimetric octahedrons of magnetite.

The archaeological site of Le Châtelet-sur-Sormonne is located at the unconformity between the Rocroi Massif (represented by the Revin Group) and the Mesozoic cover of the Paris Basin (Figure 3). Outcrops of the Revin Group occur at the site itself, suggesting that the workshop was adjacent to the quarry. The Deville Group, in turn, does not outcrop near the site. Its nearest sources are about $20 \mathrm{~km}$ to the east of Le Châtelet-sur-Sormonne.

\section{The production of whetstones in Northern Gaul}

Reconstructing the whetstone manufacturing process based on rough-outs and working debris recovered from the three workshops described above is one of the main goals of this paper. Although the general process is similar to that of the whetstone workshops identified in Britannia (Allen 2014: 9) and northern Gaul, the tools differ from workshop to workshop.

Whetstones were fashioned from detached rectangular slabs that were cut into several parallelepiped bars. At Buizingen and Nereth, the process stopped at this stage and the surfaces of the rough-outs were simply smoothed (Figures 5 and 6). Buizingen produced both parallelepiped and cylindrical whetstones, whereas at production at Le Châtelet-sur-Sormonne was limited exclusively to cylinders. Figure 6 illustrates how parallelepiped rough-outs were fashioned to obtain cylindrical whetstones with elliptic or circular cross-sections.

\subsection{Quarries and mining}

The distance between quarry and workshop appears to be an essential factor in quantifying workshop's importance. The Le Châtelet-sur-Sormonne workshop was directly at the outcrop and, judging from the large amount of waste, its production was significant. It also imported a small number of rocks from outcrops $20 \mathrm{~km}$ away.

From the amount of working debris, whetstone production in Buizingen, and especially Nereth, was modest compared to that of Le Châtelet-sur-Sormonne. The length of these sites to the outcrops was greater, corresponding to a distance covered in a day's walk. The proximity of the sources of rock exploited in a quarry was therefore essential and economically advantageous for a workshop such as Le Châtelet-sur-Sormonne involved in large-scale trade.

The majority of the original Roman quarry faces have now disappeared due, for the most part, to uninterrupted work or because they are now in densely populated areas. Bearing this in mind, it would be fruitless to search for Roman whetstones quarries in the Stavelot-Venn and Brabant-London inliers, due to the lack of rough-outs found in these areas. Evidence of Roman open pits is very rare in Belgium and restricted to the quarries near the border with 
France and to the exploitation of the famous "Arkose of Maquenoise" for querns (Picavet et al. 2011).

\section{Detached slab}

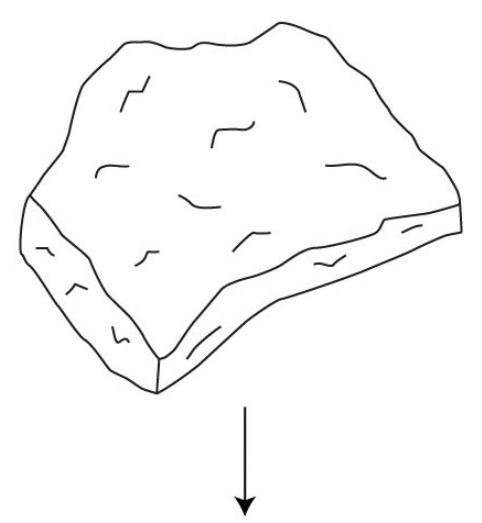

Regularising the main faces

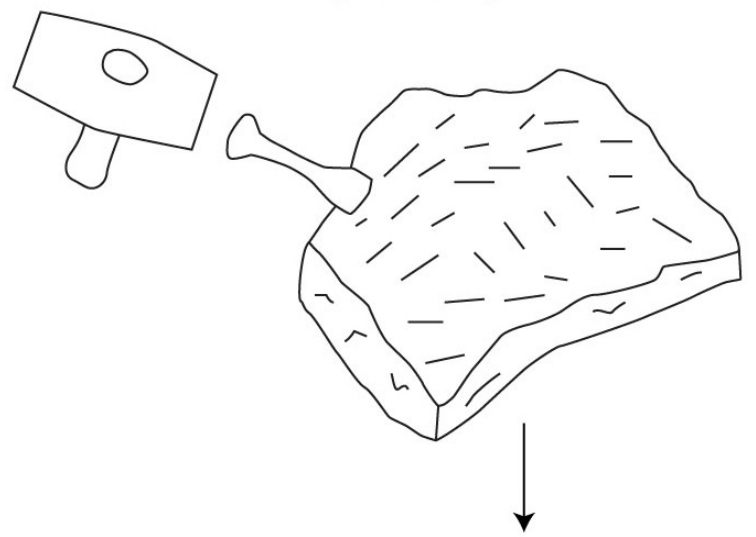

Sawing the slab
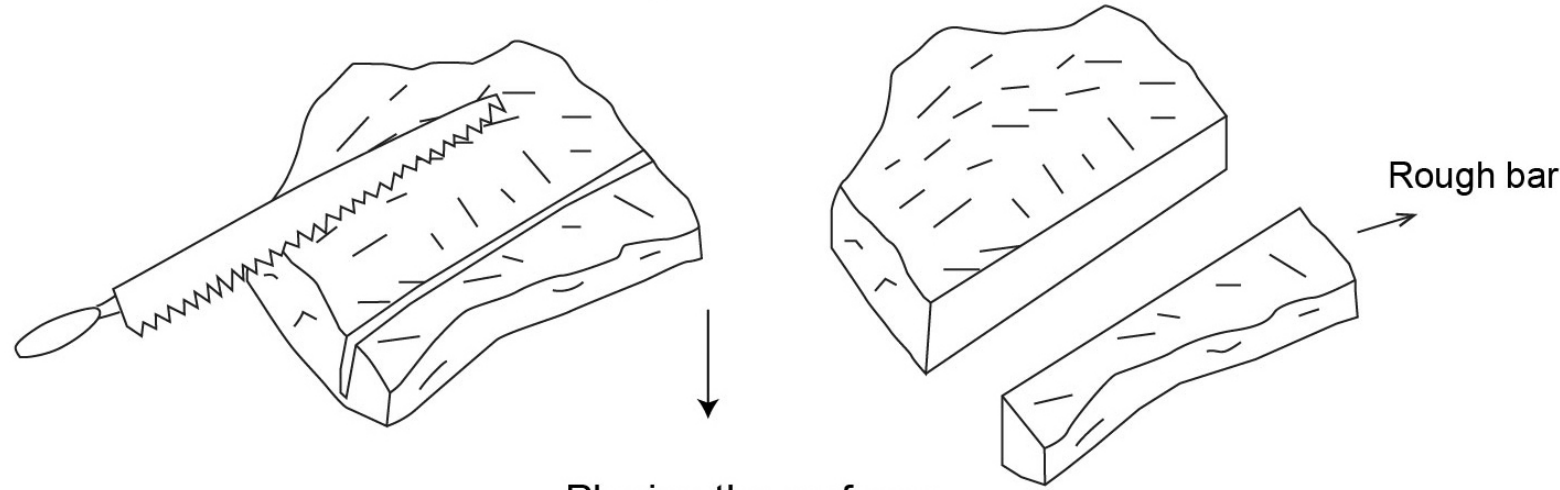

Planing the surfaces

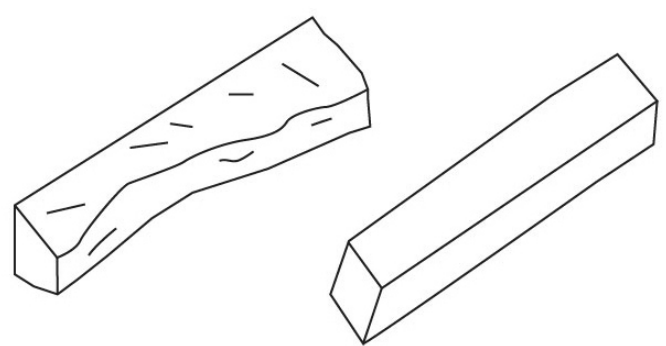

Figure 5: Reconstruction of the whetstone production sequence at the Nereth workshop. 


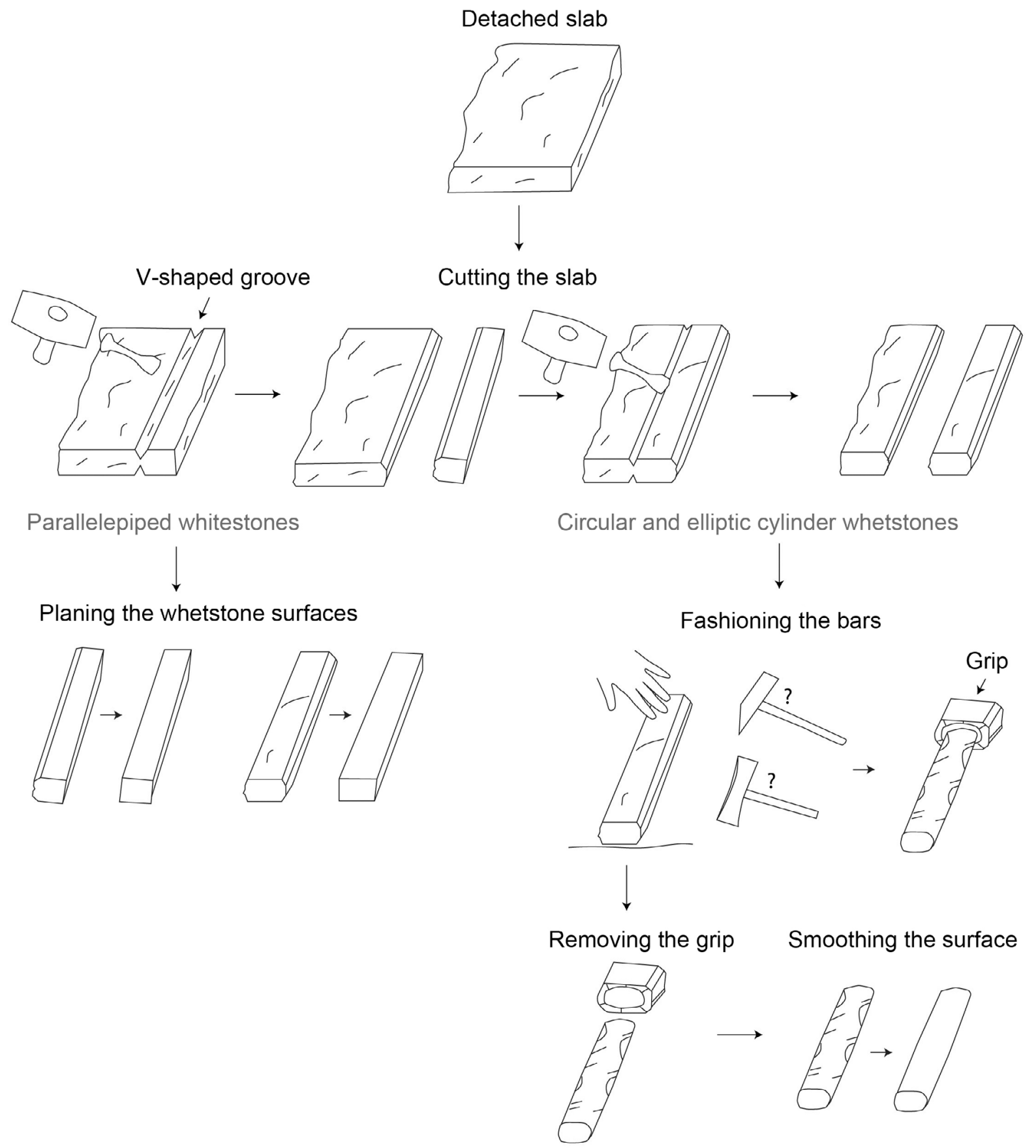

Figure 6: Reconstruction of the whetstone production sequence at the Buizingen and Le Châtelet-sur-Sormonne workshops.

Extractions from quarries took the form of flat and roughly rectangular slabs (Figures 5, 6 and 7). These rocks break naturally into slabs following the outcrop's stratification planes and networks of joints. This natural bedding tended to facilitate the whetstone maker's work. After extraction, the slabs were transferred to the workshop.

Several of these types of rough slabs were found at Buizingen and Le Châtelet-surSormonne. Yet no example was identified at Nereth. Table 1 presents the average sizes of the slabs and rough-outs. In general, most slabs and rough-outs are fragmented. Therefore, their original measurements, especially length, are not always known. 


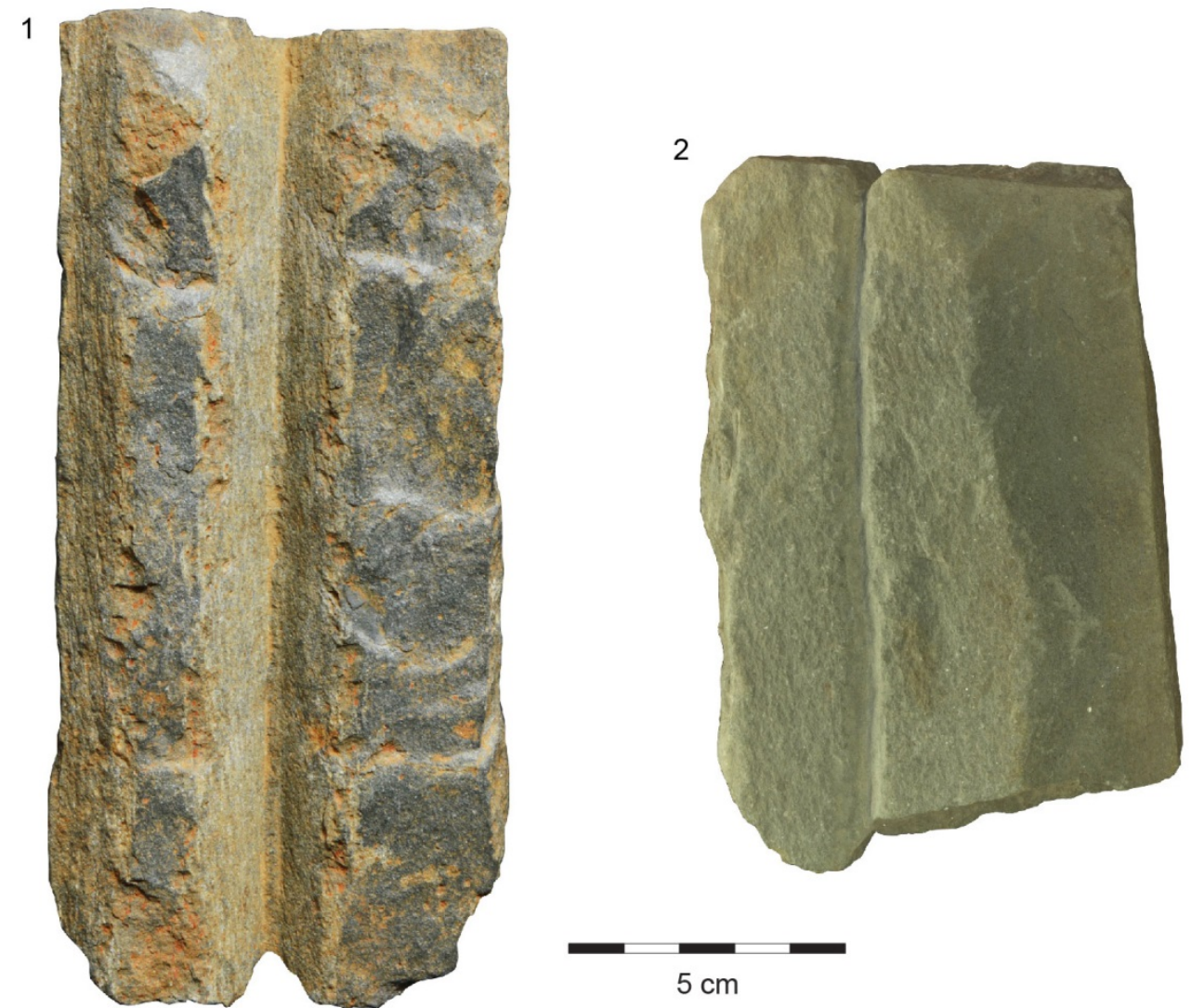

Figure 7: Slabs with V-shaped grooves from (1) Le Châtelet-sur-Somonne and (2) Buizingen.

Table 1: Average measurements ( $\mathrm{L}$ x W x T) of slabs, bars and cylindrical rough-outs from Nereth, Buizingen and Le-Châtelet-sur-Sormonne. * Size of the two well-preserved slabs.

\begin{tabular}{lccc}
\hline Workshops & Slabs $(\mathbf{c m})$ & Bars $(\mathbf{c m})$ & Cylindrical rough-outs $(\mathbf{c m})$ \\
\hline Nereth & Not available & $11.5 \times 3.4 \times 3.2$ & Not applicable \\
Buizingen & $\begin{array}{c}25 \times 21 \times 5 \text { and } \\
13 \times 8.5 \times 3.3^{*}\end{array}$ & $12 \times 3.5 \times 2.7$ & $15 \times 4.5 \times 3.5$ \\
Le Châtelet-sur-Sormonne & $18.8 \times 10.2 \times 3.9$ & $20 \times 4.6 \times 3.2$ & $\begin{array}{c}\text { Elliptic cylinder: } 16 \times 3.6 \times 2.8 \\
\text { and circular cylinder: } 17.8 \times 3.3\end{array}$ \\
\hline
\end{tabular}

\subsection{Cutting the slab}

The first stage of whetstone production involved cutting off several parallelepiped bars from a slab. This required carving parallel V-shaped grooves on the opposite faces. When the grooves were sufficiently deep, the bar was snapped off the slab by means of a sharp blow.

Traces of these grooves are visible in slabs both at Buizingen and Le Châtelet-surSormonne (Figures 6 and 7). The dimensions of the grooves vary from site to site. At Buizingen they are 0.5-0.8 cm wide and 0.3-0.6 cm deep. At Le Châtelet-sur-Sormonne, in turn, they are larger $(1.5$ to $3.5 \mathrm{~cm})$ and deeper $(1$ to $1.5 \mathrm{~cm})$. Their dimensions affected the shape of the bars. At Le Châtelet-sur-Sormonne, the bars have octagonal cross-sections, whereas at Buizingen their cross-sections tend to be more rectangular (Figures 8 and 9).

As can be seen from the slabs at Buizingen and Le Châtelet-sur-Sormonne, the grooves were carved with a single pointed or bladed chisel. Different stages of the grooving can be observed on several slabs at Le Châtelet-sur-Sormonne. The craftsman worked one face after the other. First, he cut two narrow shallow grooves 1.5 to $3.5 \mathrm{~cm}$ apart. These were then 
deepened to form the V-shaped groove. This process was then repeated on the opposite face (Figure 8). Only one bar was fashioned at a time.

Although no slabs were found at Nereth, several parallelepiped bars provide clues to a cutting process (Figure 8) that differed from that of the other two workshops. This consisted of a single groove cut with a saw. Sawing is characterised by flat faces and long, thin longitudinal striations. When the groove was deep enough, the craftsman could break off the slab resulting in an edge with a rough surface (Figure 10). Before cutting the slab, its main faces were regularised with a chisel, as seen by the marks on several Nereth bars.

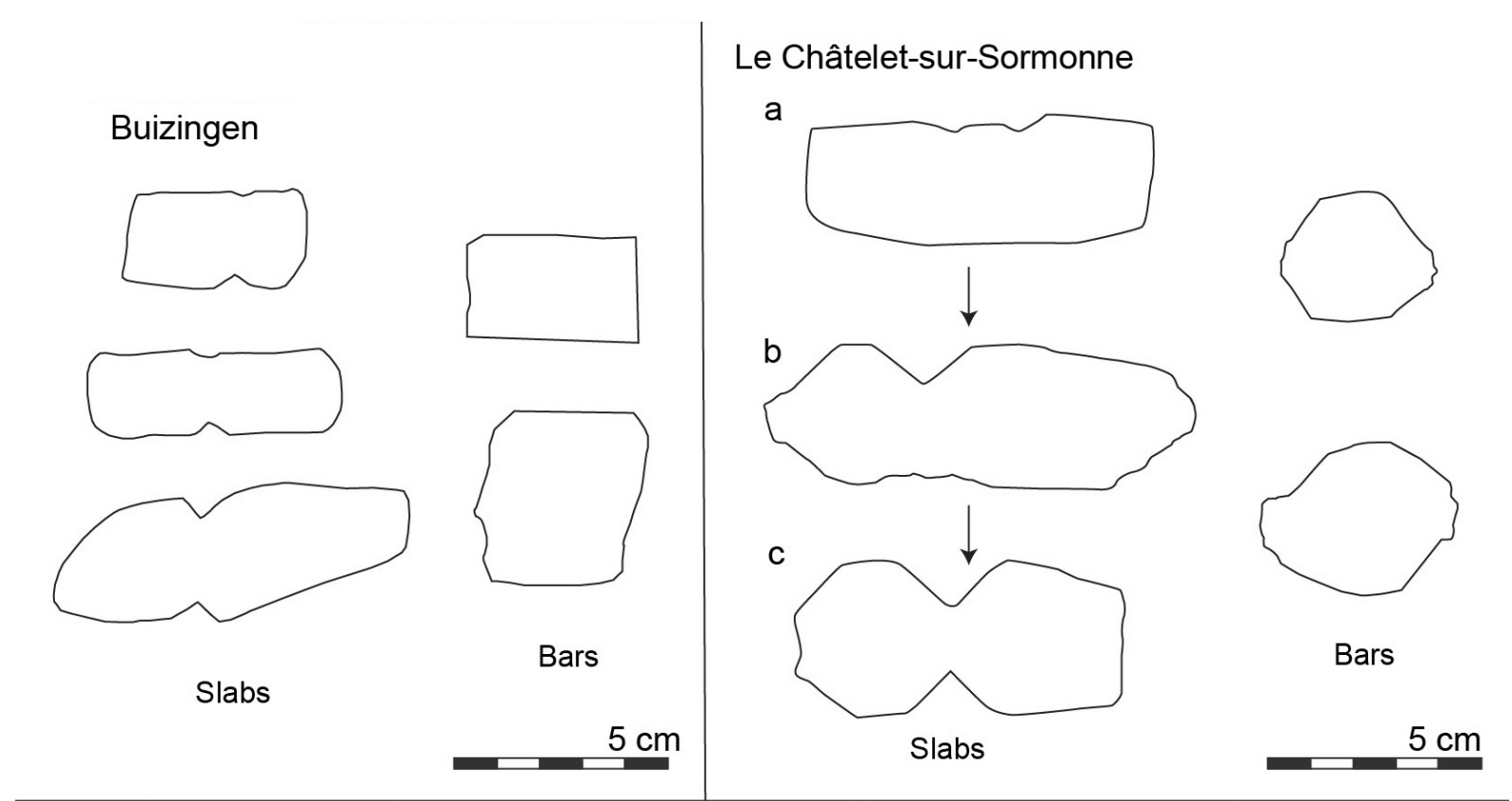

Nereth

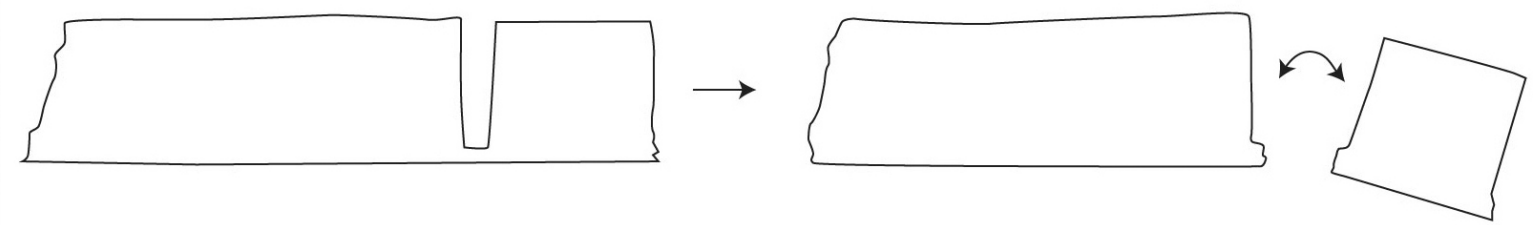

Figure 8: Sections of slabs with grooves and bars cut from slabs. Le Châtelet-sur-Sormonne: a. two narrow grooves are carved on one face, b. the final V-shaped groove is deepened, b and c. the process is repeated on the opposite face. Nereth: sawing reconstruction of a slab.

At Nereth and Buizingen, bars cut from the slab were then smoothed to obtain parallelepiped whetstones. Indeed, finished products at these two sites are evidence of this whetstone type. However, at Le Châtelet-sur-Sormonne, and in some cases at Buizingen, the process was not complete at this stage as the bars were then fashioned to obtain cylinders (Figures 5 and 6). Table 1 presents the average bar sizes from Buizingen, Le-Châtelet-surSormonne and Nereth.

\subsection{Cylindrical whetstones with elliptic and circular cross-section}

Cylindrical whetstones were produced at Buizingen and Le Châtelet-sur-Sormonne. They were carved by removing flakes presumably with a hammer along the edge of bars bearing either a rectangular (Buizingen) or octagonal cross-section (Le Châtelet-sur-Sormonne). Once the rough cylinder was completed, the final shape was attained by metal tools leaving circular and linear marks on their surface (Figures 6, 11 and 12). 


\section{1}
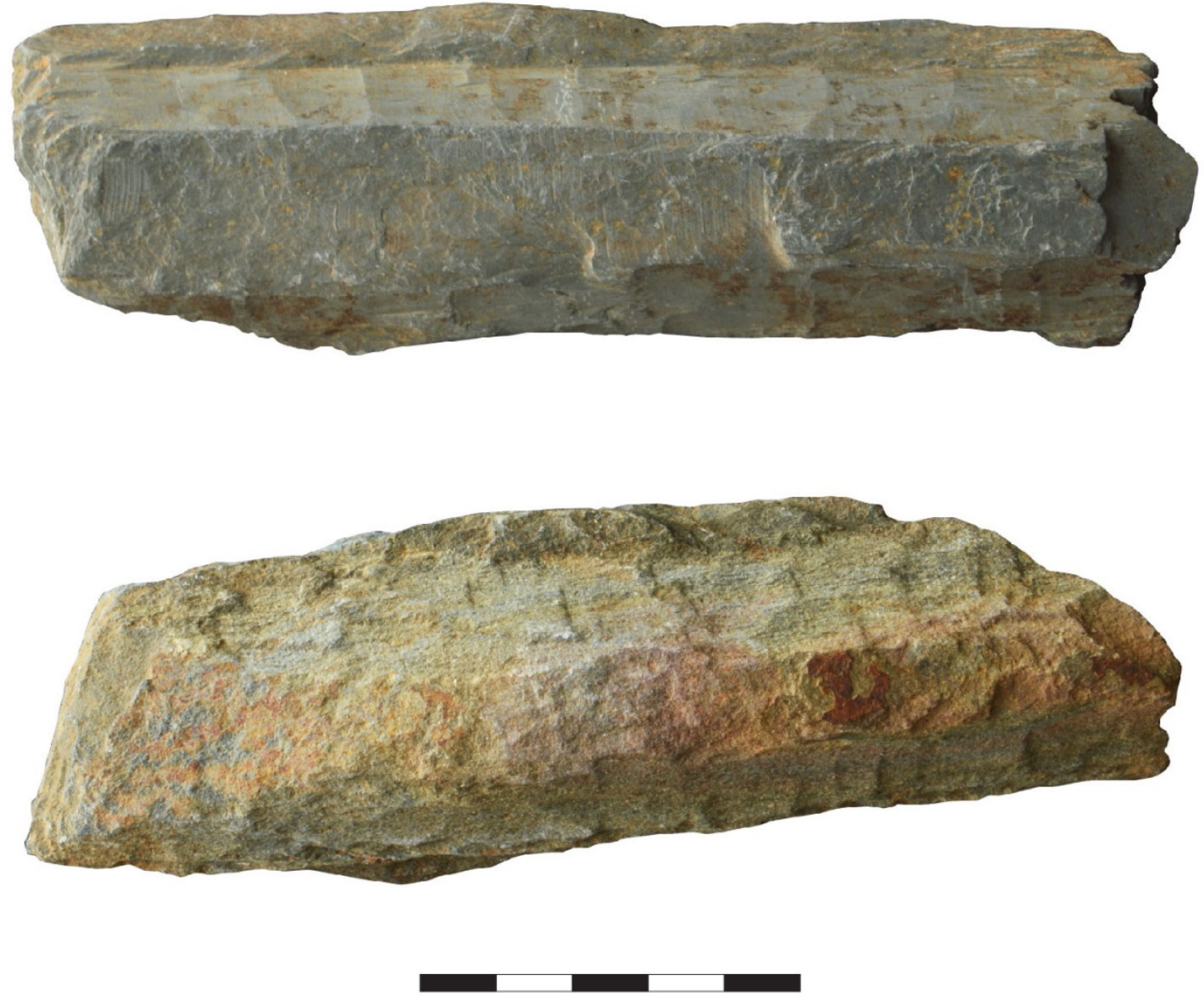

\section{$5 \mathrm{~cm}$}

2
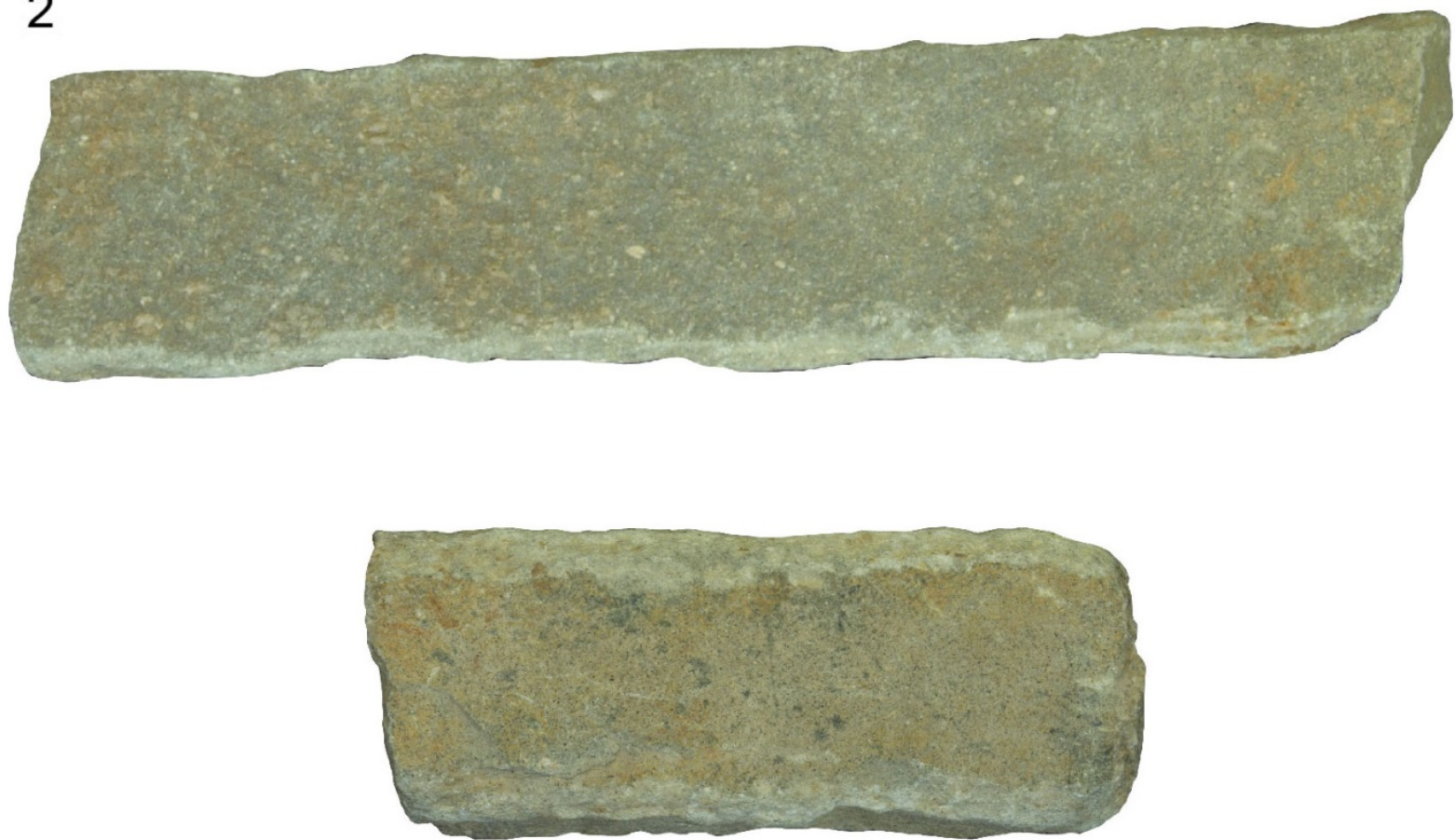

Figure 9: Bars cut from slabs found at (1) Le Châtelet-sur-Sormonne and (2) Buizingen. 


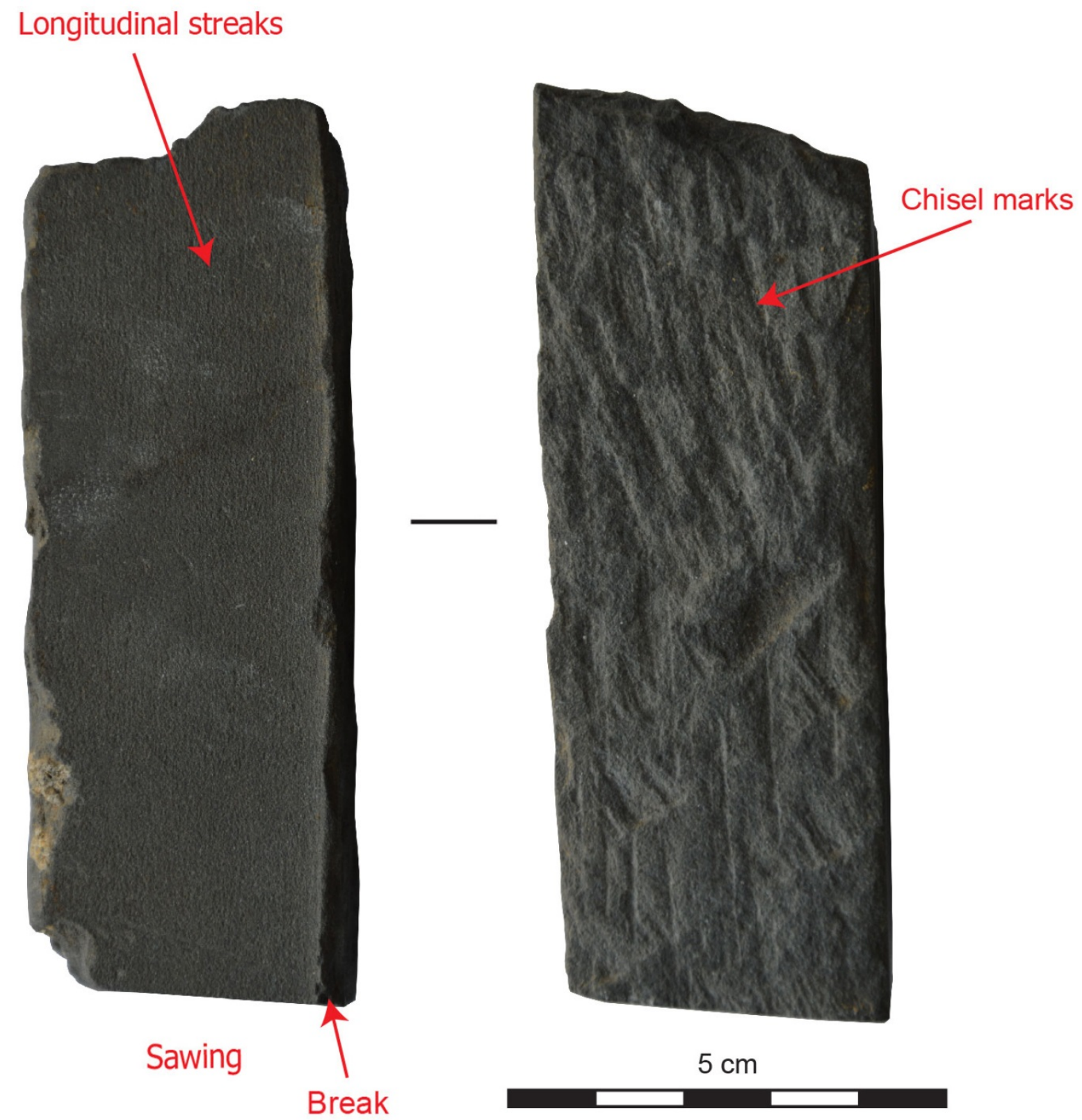

Figure 10: Parallelepiped bars cut from the slab with saw and chisel marks, Nereth.

These tool marks, corresponding to the final phases of fashioning, could have been made by an axe-hammer or a pick-axe in direct percussion. In this case of direct percussion, the cylindrical rough-out was probably held vertically by one hand with one of its ends on the ground freeing the other hand for the tool. A second option was the use of a hammer and a chisel by means of indirect percussion requiring the use of both hands. This would have called for a vice or similar tool to hold the stone firmly in place.

These products are often characterised by a rough end called a "grip" bearing traces of Vshaped grooves, while the rest of the stone is completely rounded. The grips were not fashioned because they were either held by the craftsman's hand or attached in the vice (Figure 13). 

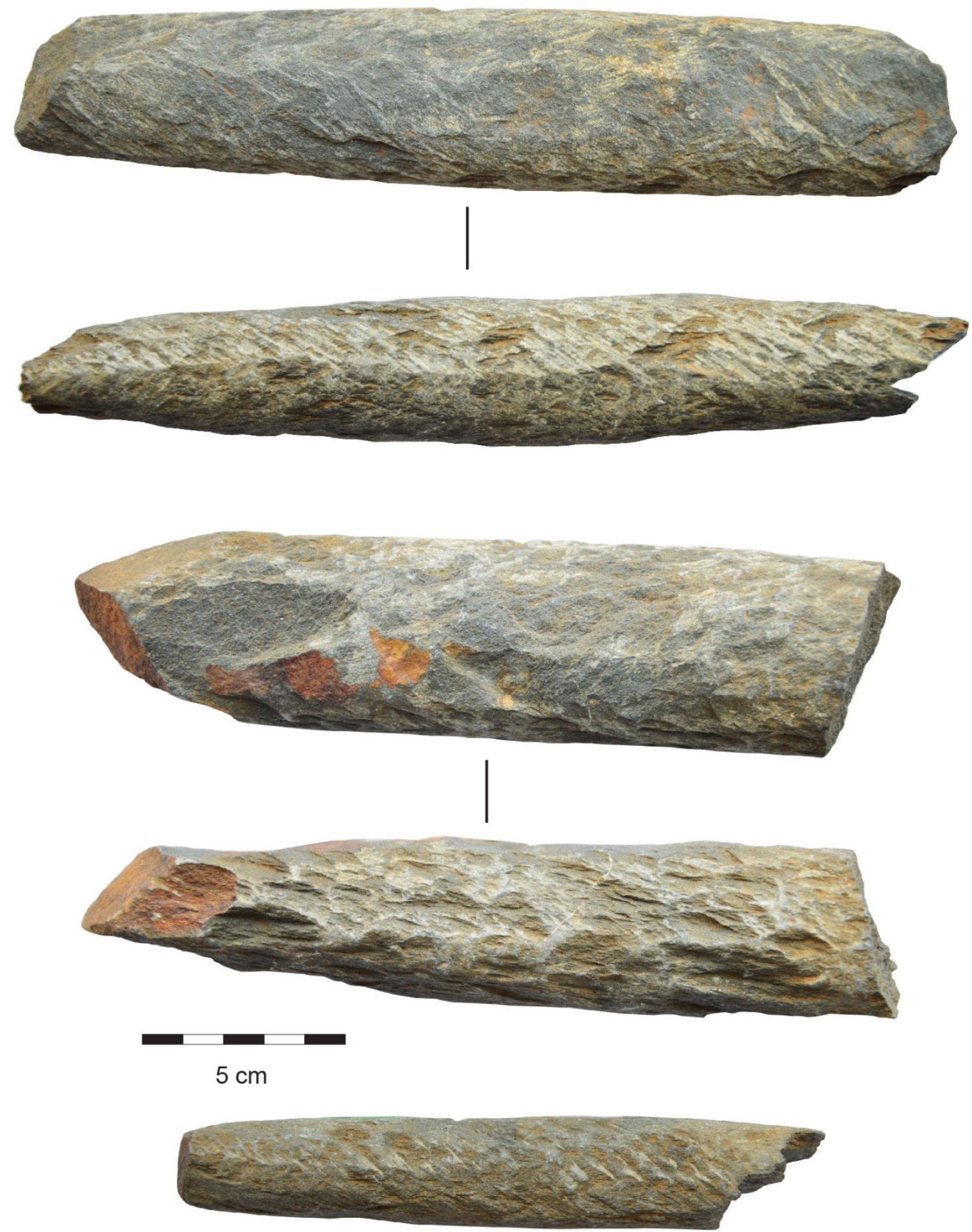

Figure 11: Cylindrical rough-outs with elliptic cross-section from Le Châtelet-sur-Sormonne. 

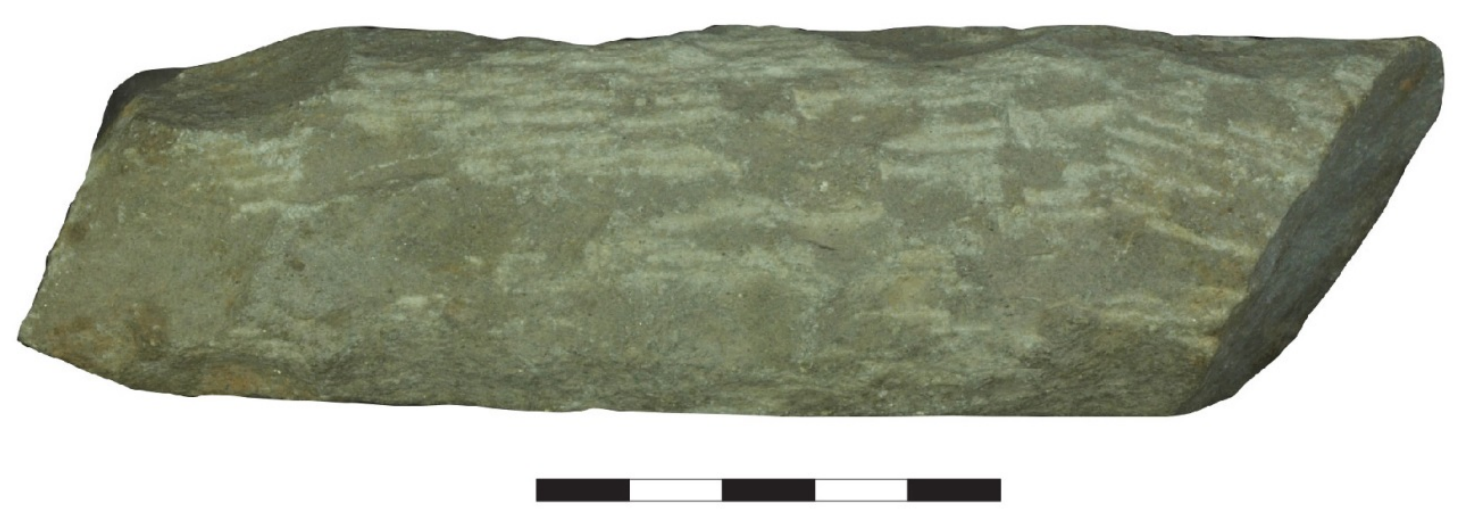

$5 \mathrm{~cm}$

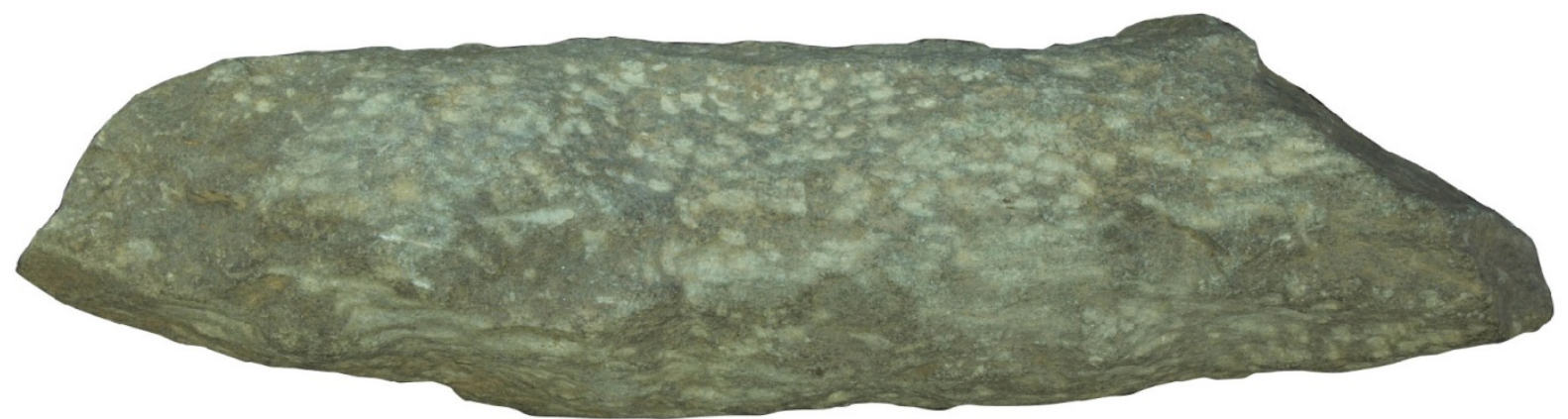

Figure 12: Cylindrical rough-outs with circular cross-section from Buizingen.

Rough grips had to be removed during the final stage of work as seen by several discarded grips among the debris at the two workshops. This technique resembled that used to cut the slab as a groove to guide the break carved along its circumference. Table 1 presents the average sizes of cylindrical rough-outs from Buizingen and Le-Châtelet-sur-Sormonne.

\subsection{Smoothing the whetstones edges}

Both cylindrical and parallelepiped whetstones produced in workshops had rough surfaces that required a final last phase of smoothing before use. A large diamond-shaped fine green sandstone (“Arkoze de Tubize”) found in the cellar at Buizingen presents an extensively worn surface and interpreted as a tool for whetstones smoothing. Similarly, a fragment of a quern with both polished and worn surfaces was also reused as a whetstone polisher. This "Arkose of Macquenoise" quern is a milky white microconglomerate strewn with dark green millimetric grains of tourmalinite and crystals of tourmaline in a matrix of whitish flakes of muscovite (recrystallized clay minerals). This follows the model of using olivine dolerite blocks in the Neolithic as "rock-to-rock" stone axe polishers found far from their sources as reported in England (Whitehead 1979).

Smoothing sharpening stones with other abrasive stones required a lot of time. In Roman times, sculptors used metal scrapers or rasps to rub down the coarse surfaces resulting from the manufacturing process (Bessac 1987: 189). Since polishing stone with a metal tool is faster than stone, it is possible to imagine that metal tools were used at Buizingen and Le Châtelet-sur-Sormonne. At Le Châtelet-sur-Sormonne, polished whetstones were perhaps "faceted", by a straight-edged tool such as a rasp. These "facets" were then removed by polishing with a fine stone, like those at Buizingen (Figure 14). 


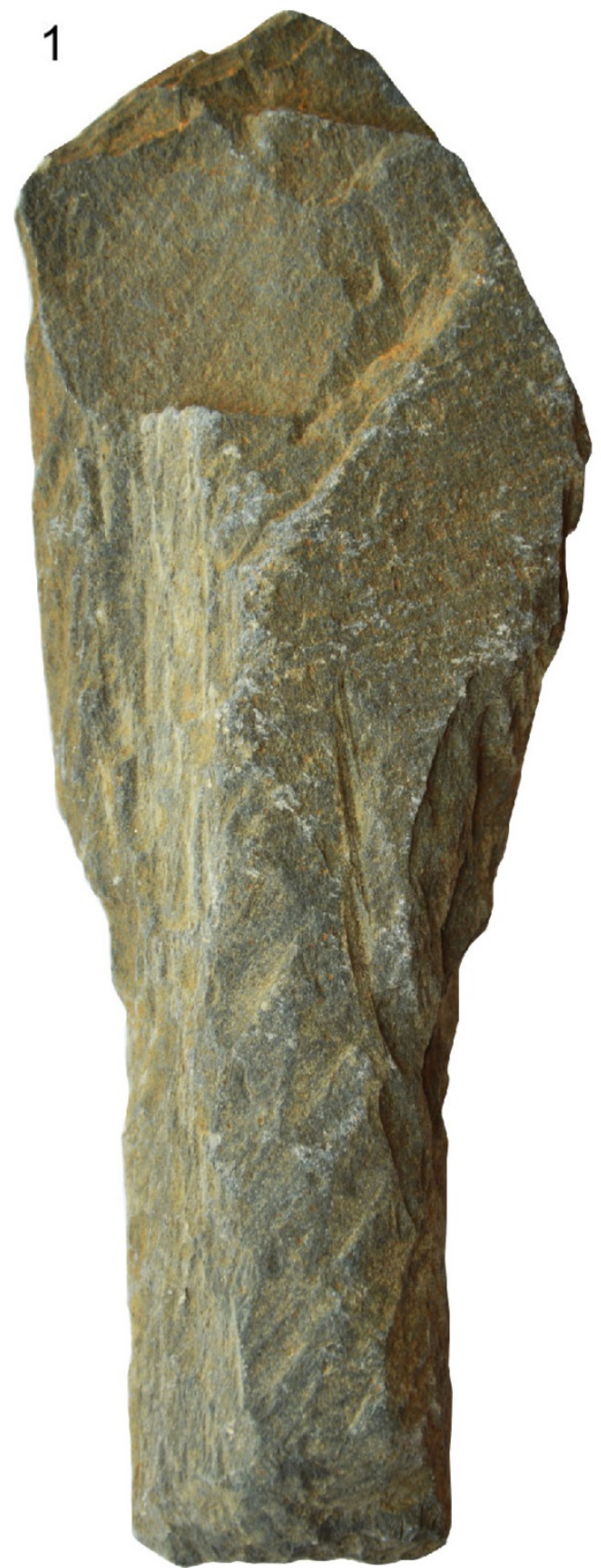

2

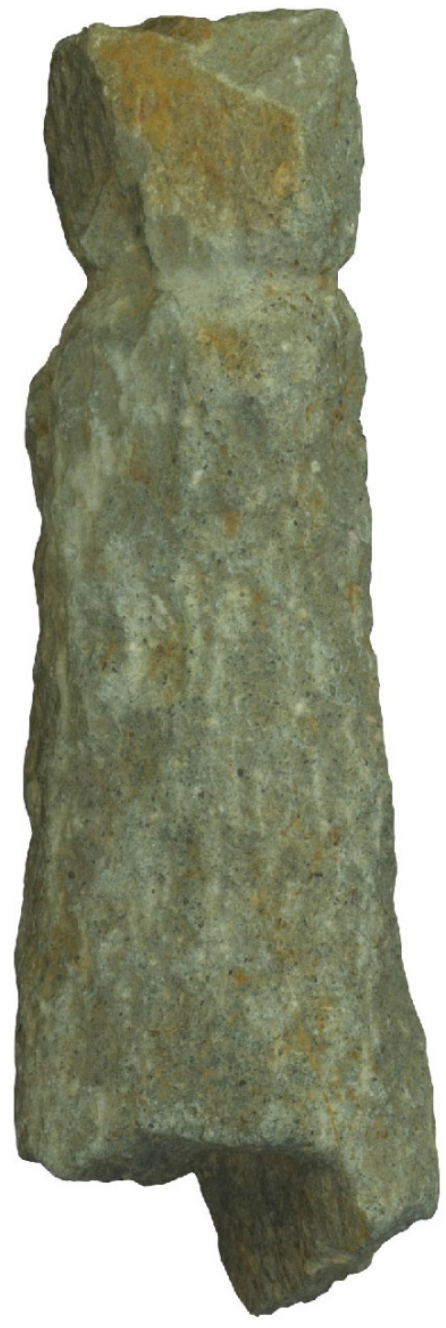

Figure 13: Unworked grips of rough-outs from (1) Le Châtelet-sur-Sormonne and (2) Buizingen. The groove of the Buizingen example was cut to remove the grip.

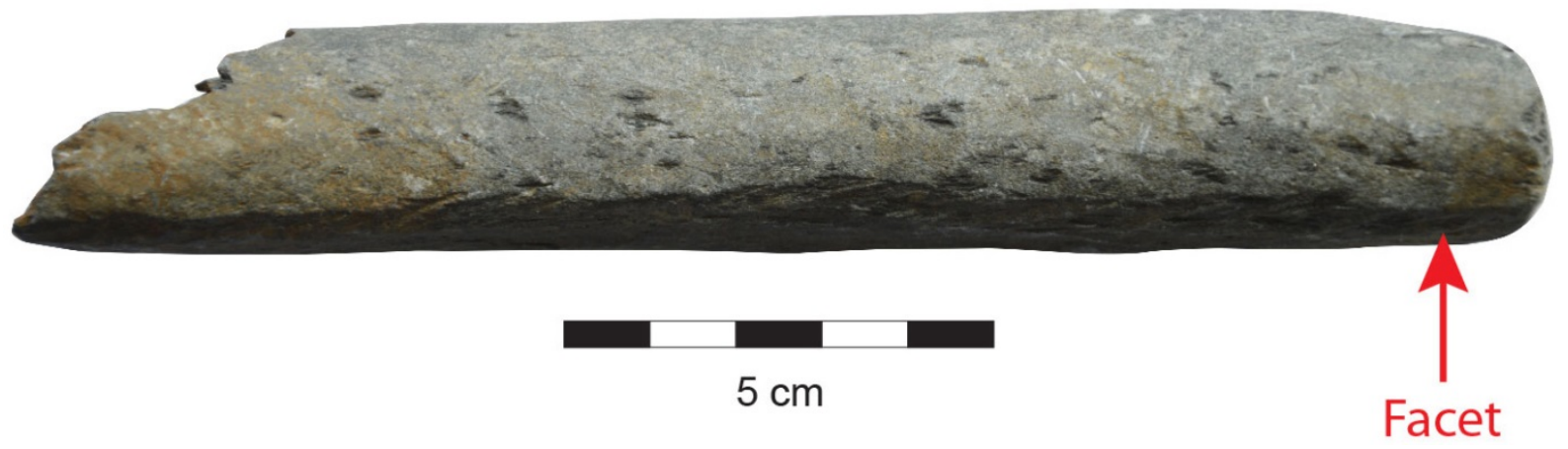

Figure 14: Polished whetstones with facets, Le Châtelet-sur-Sormonne. 


\subsection{Producing whetstones in Britannia: a different technology?}

The production processes inferred from the study of whetstones at Wroxeter (Atkinson 1942: 128-130) and the rough-outs at Usk (Manning 1995: 257-258) are very similar to those of the workshops in Gaul. Allen (2014: 9) summarised, described and compared the Usk and Wroxeter production. After extraction, each of the slab faces was grooved to produce parallelepiped bars. Grooves on the Usk slabs are triangular in cross-section and were carved by a pointed chisel. The same tool is inferred for the grooves at Buizingen and Le Châteletsur-Sormonne.

Yet the traces of these grooves on unused whetstones from Wroxeter and other sites in England indicate a different tool. Their long edges reveal rectangular rebates resulting, according to Allen (2014: 9) from cuttings with a saw, a technology also identified at Nereth.

\subsection{The spread of whetstones}

Considering the small amount of waste and rough-outs found at Nereth, we assume that production was local and limited to the site itself. The discovery of one hundred rough-outs at Buizingen, in turn, is an argument for a widespread regional distribution. However, to date, no finished whetstone from the Buizingen workshop has been identified on the sites we examine in northern Gaul, despite the fact that their macroscopic characteristics are "easily" recognisable by the trained eye.

By contrast, whetstones from Le Châtelet-sur-Sormonne were widely distributed throughout northern Gaul, from the Ardennes to the Limes (Figure 15). Indeed, many cylindrical examples have been found in northern France, Belgium, the Netherlands and Germany. Their boundary of distribution is still provisional and the map presented in this paper will certainly be modified by future research.

\section{Conclusion}

This paper presents the preliminary results of whetstone production in northern Gaul. The combination of finds of rough-outs and production waste enables us to reconstruct the manufacturing process of two whetstone types. The steps of whetstone production varied from workshop to workshop with regard to the choice of tools and the way the bars were cut. Two groove cutting processes were identified: one using a saw and the other using a hammer and chisel. These tools are also identified respectively at Wroxeter and Usk (Allen 2014: 9).

All of the whetstones found in the different workshops share common features. These include a granular texture, fine and well-sorted particles of angular or subangular quartz grains (due to their long diagenetic or metamorphic history) in a sericitic matrix. The workshops used various clastic sedimentary rocks ranging between fine siltstones and medium-grained sandstones. This diversity is encountered in a same quarry and in a natural rock outcrop due to vertical or lateral grain size variations. The quality of the edge produced on the blade, as well as the speed with which the desired edge was attained, depended on the average grain-size, the sorting and the clasticity of the rocks. This means that the production of sharpening stones with different grain size averages allowed the production of blades of different sharpness and, as a consequence, it was possible to produce metallic blades for specific purposes. The needs of a razor blade and an axe, for example, were not identical.

This paper highlights the importance of sedimentary and low-grade metamorphic rocks extracted from the Caledonian inliers, in particular those from the Rocroi Massif. Here an important whetstone industry developed during Roman times at Le Châtelet-sur-Sormonne with a widespread distribution throughout northern Gaul. The whetstone industry in the Rocroi Massif apparently emerged as the result of the Roman conquest and then disappeared 
with the demise of the Empire. To date, no cylindrical whetstones from the Rocroi Massif have been uncovered in earlier Protohistoric or later Merovingian contexts.

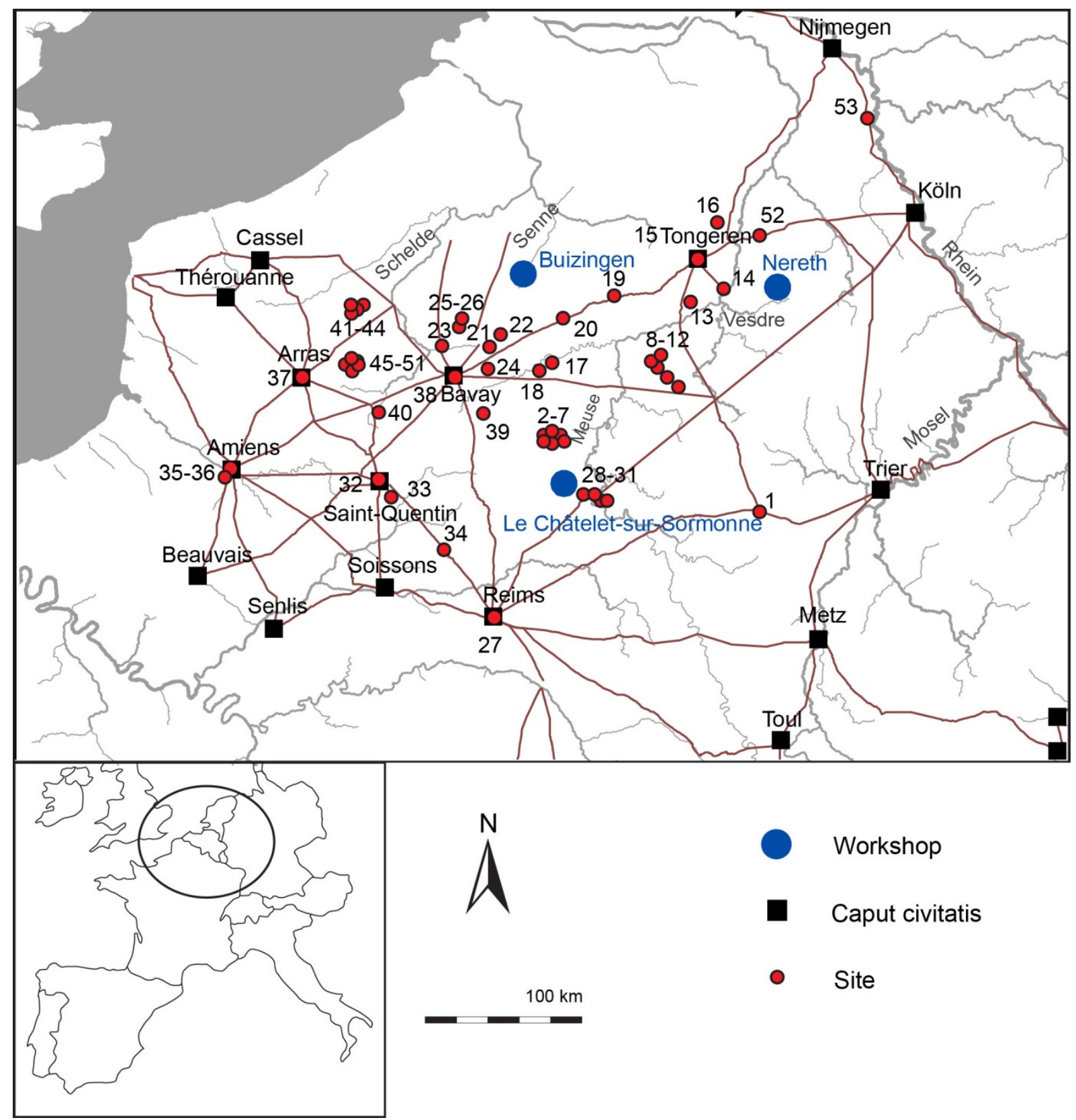

Figure 15: Sites with at least one whetstone fashioned from materials collected in the Rocroi Inlier. Belgium: 1. Arlon; 2-7. Matagne-la-Grande, Neuville, Treignes, Roly, Nismes, Fagnolle; 8-12. Hamois, Gesves, Ohey, Ciney, Jemelle; 13. Wanze; 14. Jupille-sur-Meuse; 15. Tongeren; 16. Neerharen; 17. Thy-Le-Bauduin; 18. Aiseau-Presles; 19. Taviers; 20. Liberchies; 21. Nimy; 22. Houdeng; 23. Pommeroeul; 24. Fontaine-Valmont; 25-26. Silly, Ghislenghien. France: 27. Reims; 28-31. Saint-Laurent, Ville-sur-Lumes, Warcq, Remilly-lesPothées; 32. Saint-Quentin; 33. Urvillers; 34. Laon; 35-36. Amiens, Pont-de-Metz; 37. Arras; 38. Bavay; 39. Sains-du-Nord; 40. Les-Rues-des-Vignes; 41-44. Villeneuve d’Ascq, Templemars, Seclin, Noyelles-lès-Seclin; 45-51. Brebières, Lauwin-Planque, Dechy, Guesnain, Flines-lez-Râches, Dourges, Pecquencourt. The Netherlands: 52. Heerlen. Germany: 53. Xanten.

Our future research aims to define the distribution spheres of whetstones made of other rocks types. Their workshops and chronology are still unknown. It would also be interesting to analyse whetstone production and distribution beyond the present study area, for example, in southern Gaul and along the Mediterranean coast. The study of these sharpening tools 
merits future research because they are valuable tools in our understanding the Roman economy and its industrial activities.

\section{Acknowledgements}

This research was made possible by a $\mathrm{PhD}$ grant awarded by the University of Liège (Belgium). We would like to thank P. François, curator of Zuidwestbrabants Museum in Hal, A. Noirhomme, curator of the Museum of Centre Public d'Aide Sociale in Brussels and J.-M. Pierrard, director of the Cercle d'Histoire, d'Archéologie et de Folklore d'Uccle for allowing us to study the whetstones in their collections. Our thanks also go to the Service Public de Wallonie, Direction de l'archéologie (Wallonia, Belgium) and to the Institut National de Recherches Archéologiques Préventives for granting us permission to study the artefacts from their excavations and to refer to their unpublished data. We are grateful to F. Doperé (Katholieke Universiteit Leuven) for helping us with the manufacturing marks and to I. Reygaerdts, T. Vroman and H. Critchley for their assistance in the earlier version of the draft. Both reviewers P. F. Whitehead (St. Peter's College, Oxford) and T. J. Anderson (Laboratoire de Recherche Historique Rhônes-Alpes, Grenoble) are thanked for their useful comments and for help with English grammar that greatly improved the manuscripts.

\section{References}

Allen, J.R.L. 2014, Whetstones from Roman Silchester (Calleva Atrebatum), North Hampshire. Character, manufacture, provenance and use. "Putting an edge on it". British Archaeological Report, British Series Vol. 597. Archaeopress, Oxford, 117 p.

Atkinson, D., (Ed.) 1942, The "finds" in the east portico gutter. In: Report on excavations at Wroxeter (The Roman city of Viroconium) in the county of Salop 1923-1927, Oxford University Press, Oxford: p. 128-130.

Bessac, J.-C. 1987, L'Outillage Traditionnel du Tailleur de Pierre de l'Antiquité à nos Jours. Revue Archéologique de Narbonnaise Vol. 14. Editions du CNRS, Paris, 319 p. (in French) ("Traditional tools of the mason from Antiquity to the present day")

Brulet, R., Derwet, J.-P., \& Vilvorder, F., (Eds.) 2008, Liberchies, vicus gallo-romain. Habitat de la Tannerie et Sanctuaire Tardif: Fouilles du Musée de Nivelles (19962003). Publications d'Histoire de l'Art et d'Archéologie de l'Université Catholique de Louvain 112. Presses de l'Université Catholique de Louvain-la-Neuve, Louvain-laNeuve, 403 p. (in French) ("Liberchies, gallo-roman vicus. Tannery settlement and late sanctuary: Nivelles museum excavations (1996-2003)”)

Chardron-Picault, P., \& Pernot, M., (Eds.) 1999, Un Quartier Antique D’Artisanat Métallurgique à Autun (Saône-et-Loire): Le Site du Lycée Militaire. Document d'Archéologie Française 76. Editions de la Maison des Sciences de l'Homme, Paris, 320 p. (in French) ("An ancient metallurgical district in Autun (Saône-et-Loire): The Lycée militaire settlement”)

Deberge, Y., Collis, J., \& Dunkley, J., (Eds.) 2007, Le Patûral, Clermont-Ferrand, Puy-deDôme. Un Etablissement Agricole Gaulois en Limagne d'Auvergne. Documents d'archéologie en Rhône-Alpes et en Auvergne 30. Association de Liaison pour le Patrimoine et l'Archéologie en Rhône-Alpes et en Auvergne, Lyon, 338 p. (in French) ("Le Patûral, Clermont-Ferrand, Puy-de-Dôme. A gallic agricultural settlement in Limagne d'Auvergne”) 
Dreesen, R., Coquelet, C., Creemers, G., Declercq, W., Fronteau, G., Gluhak, T., Hartoch, E., Heinrich, P., Lafitte, J.-D., Picavet, P., Reniere, S., Ruppiene, V., Thiébaux, A., Vanderhoeven, A., Vynckier, G., \& Goemaere, E. 2014, Unravelling geographical and geological sources of geological raw materials used as ornamental stones, millstones and whetstones from the Roman period in Belgium: A mutual favourable cross-border collaboration between geologists and archaeologists. Journal of the European Federation of Geologists, 38: 14-20. URL: http://eurogeologists.eu/european-geologistjournal/

Duchêne, B., (Ed.) 2014, Le Châtelet-sur-Sormonne (Ardennes), «Le Tranliau-Lot 1 », une Fenêtre sur l'Histoire du Châtelet-sur-Sormonne (Autoroute A 304): Habitats et Artisanats du $V^{e}$ Siècle avant notre Ere au XI $I^{e}$ de notre Ere, Espaces Funéraires à Crémation et son Etablissement Thermal Antique. Excavations report. Institut national de recherches archéologiques preventives, Metz, 601 p. (in French) ("Le Châtelet-surSormonne (Ardennes), "Le Tranliau-Lot 1", a window on the history of Le Châteletsur-Sormonne (Highway A304): Settlements and crafts from $5^{\text {th }}$ century BCE to $11^{\text {th }}$ century CE, cremation funerary spaces and its ancient thermal bath establishment”)

Fielitz, W., \& Mansy, J.-L. 1999, Pre- and synorogenic burial metamorphism in the Ardenne and neighbouring areas (Rhenohercynian zone, central European Variscides. Tectophysics, 309(1): 227-256. doi:10.1016/s0040-1951(99)00141-9

Goemaere, E., (Ed.) 2007, Ardoise et Coticule en Terre de Salm. Des Pierres et des Hommes. Service Géologique de Belgique, Brussels, 408 p. (in French) ("Slate and coticule in the region of Salm. Stones and men”)

Goemaere, E., Demarque, S., Dreesen, R., \& Declercq, P.-Y. 2015, The geological and cultural heritage of the Caledonian Stavelot-Venn Massif, Belgium. Geoheritage: 1-23. doi:10.1007/s12371-015-0155-y

Hanut, F., Goemaere, E., Thiébaux, A., \& Goffioul, C. 2013, Baelen/Baelen: l’Établissement rural germanique de Nereth. Synthèse de l'étude du mobilier archéologique. Chronique de l'archéologie wallonne, 20: 150-156. (in French) ("Baelen/Baelen: Rural Germanic settlement of Nereth. Study of the archaeological finds").

URL: http://hdl.handle.net/2268/160919

Hanut, F., Goffioul, C., \& Goemaere, E. 2012, L'établissement germanique du Bas-Empire à Baelen/Nereth, province de Liège (Belgique). In: The very beginning of Europe? Cultural and social dimensions of Early-Medieval migration and colonisation $\left(5^{\text {th }}-8^{\text {th }}\right)$. Archaeology of contemporary Europe; Proceedings of the conference, May 17-19 2011, Brussels, (Annaert, R., Jacobs, T., In't Ven, I., \& Coppens, S., Eds.), Relicta Monografieën 7. Flanders Heritage Agency, Brussels: p. 243-254. (in French) ("Late empire Germanic settlement in Nerteh/Baelen, Liège (Belgique)").

URL: https://oar.onroerenderfgoed.be/publicaties/RELM/7/RELM007-001.pdf

Henrich, P., Mischka, C., \& Perret, S. 2008, Die römische Villa mit spätantiker Schmiede von Oberbettingen Hillingweise, Landkreis Vulkaneifel. Funde and Ausgrabungen im Bezirk Trier, 40: 84-94. (in German) ("The Roman villa with a late Empire forge von Oberbettingen Hillingweise, Landkreise Vulkaneifel”)

Herbosch, A., Dumoulin, V., Blockmans, S., \& Debacker, S. 2013, Carte Géologique de Wallonie. Ittre-Rebecq n³9/1-2, 1/25000. Service Public de Wallonie, Namur, 114 p. (in French) (“Geological map of Wallonia, Ittre-Rebecq n³9/1-2, 1/25000”) 
Kars, H. 1983, Early-Medieval Dorestad, an archaeological study. Berichten van de Rijksdienst voor het Oudheidkundig Bodemonderzoek, 33: 1-37.

Manning, W.H. 1995, Honestones. In: Report on the Excavations at Usk 1965-1976. The Roman Small Finds, (Manning, W.H., Price, J., \& Webster, J., Eds.), University of Wales, Cardiff: p. 257-263.

Picavet, P., Fronteau, G., \& Boyer, F. 2011, Les meules romaines de sept chefs-lieux de cité de Gaule Belgique occidentale, étude du matériel et synthèse bibliographique. Revue $d u$ Nord, 93(393): 167-226. (in French) (“The Roman millstones of seven capitals of western Gallia Belgica, a study of the material and a bibliographical synthesis”). doi:10.3917/rdn.393.0167

Pierrard, J.-M. 2010a, Découverte d'un atelier romain de pierres à aiguiser. Ucclensia, 229: 512. (in French) ("Discovery of a Roman whetstone workshop”)

Pierrard, J.-M. 2010b, Découverte d'un atelier romain de pierres à aiguiser (II). Ucclensia, 230: 11-16. (in French) ("Discovery of a Roman whetstone workshop (II)”)

Pierrard, J.-M. 2011a, Découverte d'un atelier romain de pierres à aiguiser (III). Ucclensia, 233: 2-10. (in French) (“Discovery of a Roman whetstone workshop (III)”)

Pierrard, J.-M. 2011b, Découverte d'un atelier romain de pierres à aiguiser (IV). Ucclensia, 234: 14-19. (in French) ("Discovery of a Roman whetstone workshop (IV)”)

Thiébaux, A., \& Goemaere, E. 2013, Etude des pierres à aiguiser provenant de cinq sites gallo-romains des Vallées des Eaux-Vives (sud-ouest de la province de Namur, Belgique). Archéo-Situla, 32-33: 69-79. (in French) ("Study of whetstones from five gallo-roman sites from Vallées des Eaux-vives (south-west of the Namur province, Belgium)”). URL: http://hdl.handle.net/2268/171390

Thiébaux, A., \& Goemaere, E. in press, Considérations sur quelques éléments en pierre exhumés du site Lazzari (Arlon). In: L'atelier de Foulon du Site Romain de Lazzari à Arlon, (Henrotay, D., Ed.), Service public de Wallonie, Namur. (in French) ("Regards on some lithic artefacts found in Lazzari settlement in Arlon”)

Thiébaux, A., Goemaere, E., \& Herbosch, A. 2012, Un atelier gallo-romain de pierres à aiguiser découvert à Buizingen (Hal, Belgique): Reconstitution des étapes de fabrication et détermination des origines géologiques et géographiques du matériau. Revue du Nord, 94(398): 143-158. (in French) (“A gallo-roman whetstones workshop uncovered in Buizingen (Hal, Belgium): Manufacturing process and determination of geological and geographical material origins”). doi:10.3917/rdn.398.0143

Van der Velde, H.M., Ostkamp, S., Veldman, H.A.P., \& Wyns, S., (Eds.) 2009, Venlo aan de Maas van vicus tot stad. ADC ArcheoProjecten, Amersfoort, 1094 p. (in Dutch) ("Venlo on the Maas, from the vicus to the town").

URL: https://www.academia.edu/19592787/2009_Venlo_aan_de_Maas._Van_vicus_tot _stad_deel_2_

Verniers, J., Herbosch, A., Vanguestaine, M., Geukens, F., Delcambre, B., Pingot, J.-L., Belanger, I., Hennebert, M., Debacker, M., Sintubin, M., \& De Vos, W. 2001, Cambrian-Ordovician-Silurian lithostratigraphic units (Belgium). Geologica Belgica, 4(1-2): 5-38. URL: http://popups.ulg.ac.be/1374-8505/index.php?id=1919

Waterlot, G., Bonte, A., Destombes, J.P., \& Lemoine, M. 1960, Renwez. Carte Géologique de la France à 1/50 000, (68). Service de la carte géologique de la France, Paris. (in French) (“Renwez. Geological map of France, 1:50 000, (68)”) 
Whitehead, P.F. 1979, Neolithic axes in the south-west Midlands. Vales of Evesham Historical Society Research Papers, 7: 25-30.

Whitehead, P.F. 2013, A pictorial guide to whetstones and related artefacts in Worcestershire during the past 4000 years. Worcestershire record, 34: 28-33.

URL: http://www.wbrc.org.uk/WORCRECD/34/Whitehead_Paul-A_pictorial_field_guide_to_whetsto.html 